\title{
AN OVERVIEW OF THE PHYSICAL OCEANOGRAPHY OF THE GULF OF CALIFORNIA
}

\author{
M.F. LAVÍN AND S.G. MARINONE \\ Departamento de Oceanografía Física, CICESE \\ Ensenada, Baja California, México.
}

\begin{abstract}
The Gulf of California (GC) presents several oceanographic features that make it unique among semienclosed seas of similar latitude and dimensions, the most important being strong tidal mixing, some of it close to deep stratification. Three-dimensional numerical model results suggest that tidal mixing may be more important than the thermohaline circulation in causing the long-term residual circulation, which consists of outflow in the upper $200 \mathrm{~m}$ and inflow below, plus a seasonally-reversing surface layer. The $\mathrm{GC}$ is an evaporative basin, but in the mean it gains heat through the surface. Lacking a sill at the point of connection with the Pacific Ocean (PO), the GC is constantly shaken by a wide spectrum of signals coming from the PO, including tides, subinertial trapped waves of various frequencies and El Niño. The seasonal dynamics and thermodynamics of the GC are dominated by the PO, not by local wind or buoyancy flux. Local processes are important at shorter time scales and in altering the thermohaline characteristics of the upper-layer waters. Tidal currents generate internal tides, packets of solitons, and sea surface temperature fronts from which jets may form. Coastal upwelling also seems to generate jets that separate from capes, especially on the mainland coast. The mesoscale off-shore circulation in the GC consists of a series of basin-wide geostrophic gyres that reach below $1000 \mathrm{~m}$; their effect on the mean and seasonal circulation and thermodynamics of the GC remains to be studied. During summer, the currents in the mainland continental shelf are due to coastal trapped waves, while during winter they are wind-driven. The most important interannual anomalies in the GC are due to El Niño.
\end{abstract}

Key words: Gulf of California, physical oceanography

\section{Introduction}

We present in this article an overview of the current understanding of the Physical Oceanography of the Gulf of California (henceforth GC), which has advanced considerably in the last two decades. The normal variety of observational and modelling techniques have been used, including direct and satellite measurements, data bank mining and 3D numerical modelling. 


\section{Physiography and water masses}

The GC is $1400 \mathrm{~km}$ long and its width in the inner region is $150-200$ $\mathrm{km}$ (Figure 1). In this article, the Gulf of California is divided into several provinces, indicated in Figure 1: (a) The entrance zone, in open communication with the Eastern Tropical Pacific Ocean (ETPac) through a line from Cabo San Lucas to Cabo Corrientes ("the outer mouth"). (b) The Southern Gulf of California (SGC) covers from the Cabo San Lucas-El Dorado line ("the inner mouth") to just south of the sills of the large islands. (c) The archipelago, or midriff islands zone has several narrow channels and sills whose maximum depths are between 300 and $600 \mathrm{~m}$ (Figures 1 and 2). (d) The Northern Gulf of California (NGC), which has shelf sea the characteristics. (e) The Upper Gulf of California (UGC) is the very shallow (depth $<30 \mathrm{~m}$ ) province north of $31^{\circ} \mathrm{N}$.

The laterally-averaged vertical distribution of the water masses in the GC is sketched in Figure 2, together with the water-mass classification of Torres Orozco (1993); the T-S diagram from most of the available data inside the GC is shown in the inset of Figure 1. The water masses of the GC have been reviewed by Bray and Robles (1991) and Badan-Dangon (1998).

The Pacific Deep Water (PDW) has a salinity that increases toward the bottom. The Pacific Intermediate Water (PIW) is characterized by a salinity minimum $\left(\mathrm{S}_{\min }=34.50\right.$, inset in Figure 1$)$ centered at about $900 \mathrm{~m}$. The Subtropical Subsurface Water (StSsW) is found approximately between 150 and $500 \mathrm{~m}$; in the ETPac it has a well marked salinity maximum in the thermocline. The Tropical Surface Water (TSW) is formed from StSsW by upwelling in the ETPac, where its salinity is lowered to 33 by the excess of rainfall over evaporation (Wyrtki, 1966, 1967), but off SW Mexico its salinity exceeds 34 . The California Current Water (CCW: $\mathrm{S}<34.5,12 \leq \mathrm{T}$ $<18^{\circ} \mathrm{C}$ ) does not appear in Figure 2 because of its volume inside the gulf; its presence inside the gulf has always been reported close to the mouth.

The Gulf of California Water (GCW) has salinity $\geq 35$, but because of its high temperature, it is always found in the upper layers. The ultimate main source water for the GCW is the Subtropical Surface Water of the central South Pacific, either via StSsW or TSW. The most important transformation is probably StSsW + evaporation $\Rightarrow$ GCW (Bray, 1988b; Torres Orozco, 1993; Lavín et al., 1995); it occurs mainly in the northern GC where the process is aided by vertical mixing produced by tidal currents, wind and winter convection.

Some winters, a fraction of the GCW formed in the NGC undergoes bottom water formation, evidenced by bottom salinity maxima in Wagner basin, which extend further south at mid-depth (Alvarez-Borrego and 


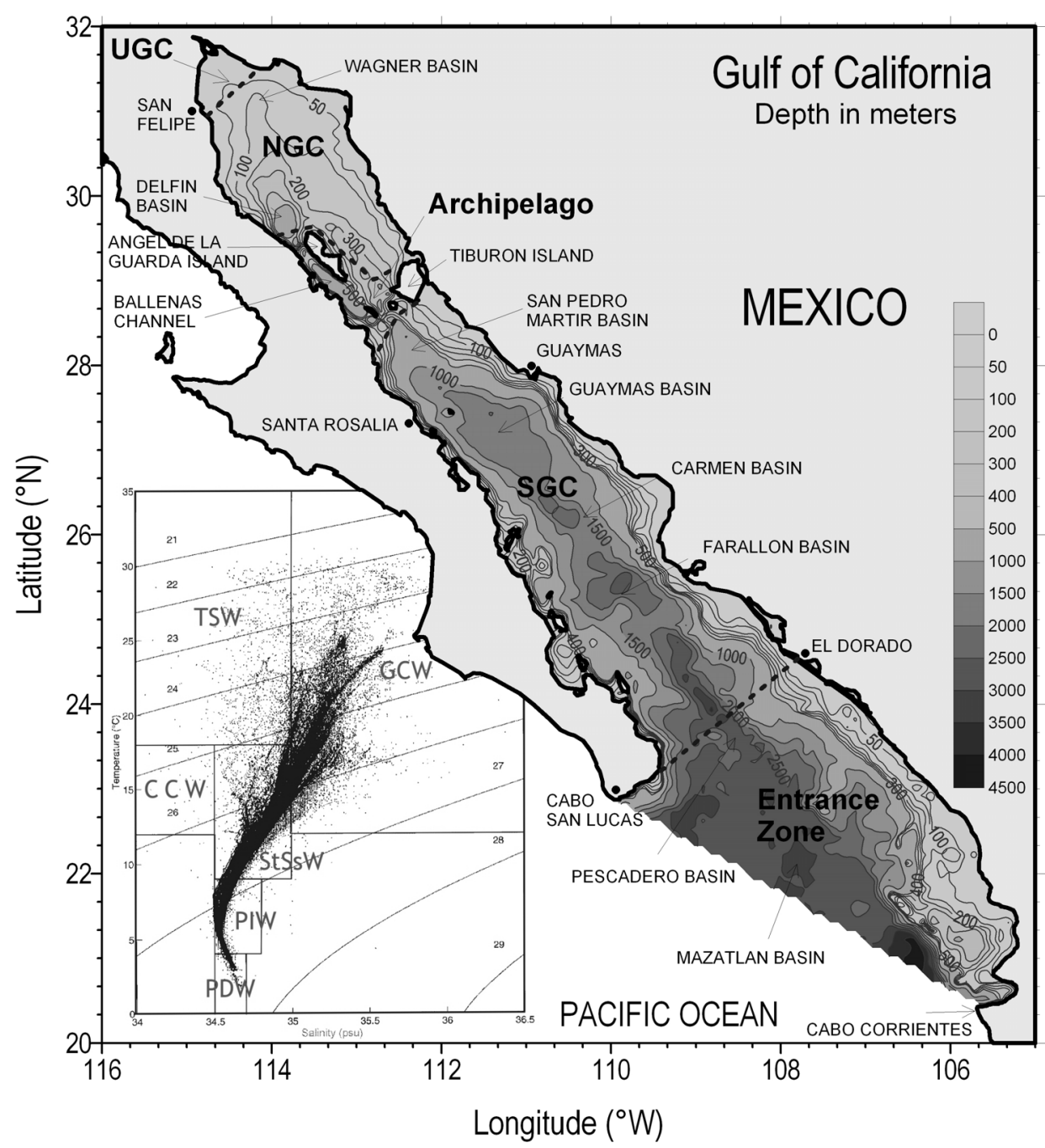

Figure 1. Bathymety of the Gulf of California (depth in meters), with named places and basins. Inset: Temperature-Salinity diagram with all the GC CTD data from 1939 to 1993. SGC, NGC and UGC, see text.

Schwartzlose, 1979; Bray, 1988b; Lavín et al. 1995; López, 1997). The process appears to occur during events of intense northwesterly winds, whose cold dry air enhances evaporation and surface heat loss (Bray, 1988a; Reyes and Lavín, 1997; López, 1997). 


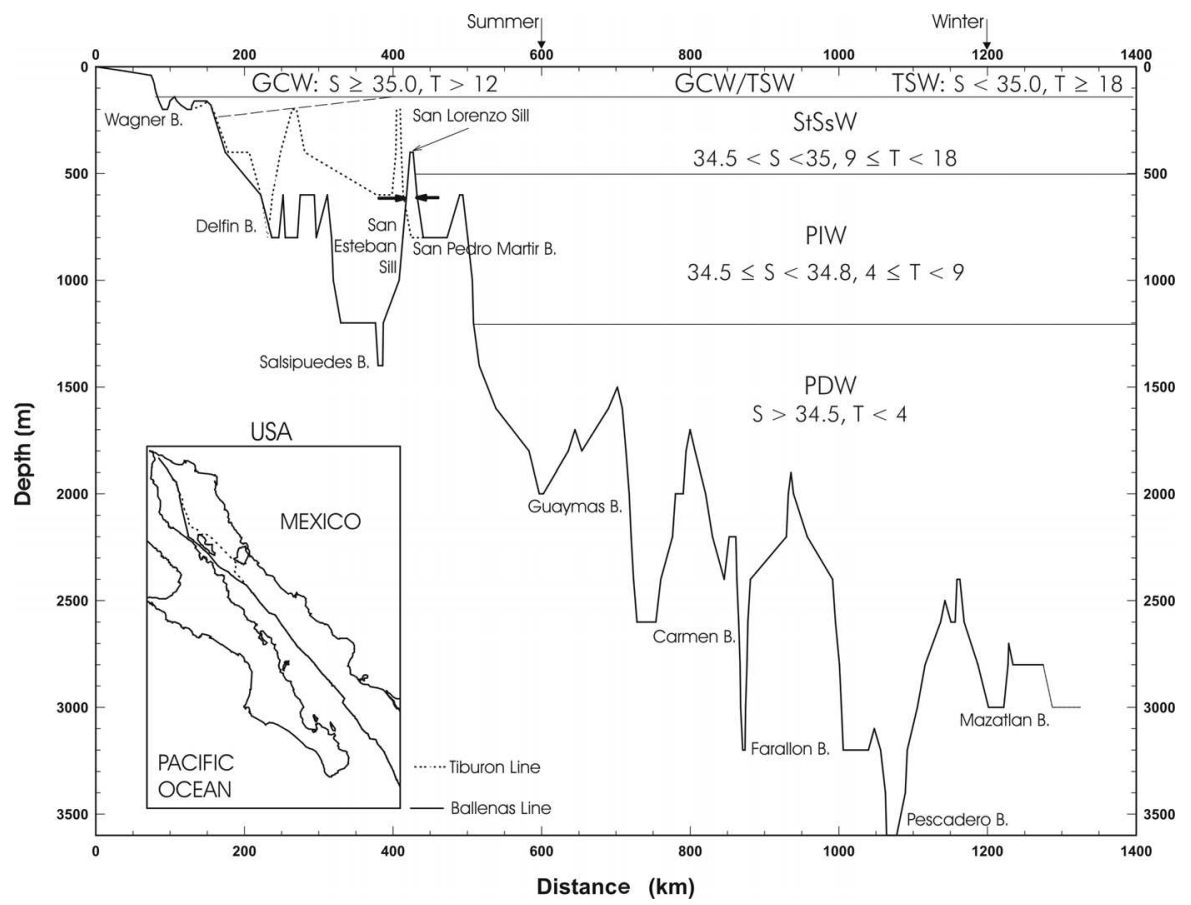

Figure 2. Sketch of the laterally-averaged distribution of water masses in the Gulf of California. Bathymetry along the lines shown in the inset map.

\section{Tides and Tidal Mixing}

Tides in the GC are produced by co-oscillation with the tides of the Pacific Ocean (Filloux, 1973; Ripa and Velázquez, 1993). The observed cotidal charts of the main tidal constituents inside the GC (Morales and Gutiérrez, 1989) are very well reproduced by barotropic numerical models (Marinone, 2000 , and references therein). The semidiurnal components show amplification in tidal height toward the head of the gulf; for M2 from $36 \mathrm{~cm}$ in the gulf entrance to $150 \mathrm{~cm}$ in the UGC, with a minimum in the central gulf of $5 \mathrm{~cm}$ where a virtual amphidromic region is found. The amplification of the semidiurnal frequencies occurs because the GC is almost resonant at those frequencies. By contrast, the diurnal components are basically in phase in the entire gulf and amplitude increases toward the head by continuity.

As a consequence of the different character of the diurnal and semidiurnal components, the tides in the gulf are mixed; mainly semidiurnal in the northern and southern zones and diurnal in the central gulf. Figure 3 shows the form factor, defined as $[\mathrm{A}(\mathrm{O} 1)+\mathrm{A}(\mathrm{K} 1)] /[\mathrm{A}(\mathrm{M} 2)+\mathrm{A}(\mathrm{S} 2)]$, where $\mathrm{A}(.$.$) is$ the amplitude of the indicated constituent. There is a large springs-neaps difference in tidal range (Figure $3 \mathrm{~b}$ and $\mathrm{c}$ ), especially in the UGC. 


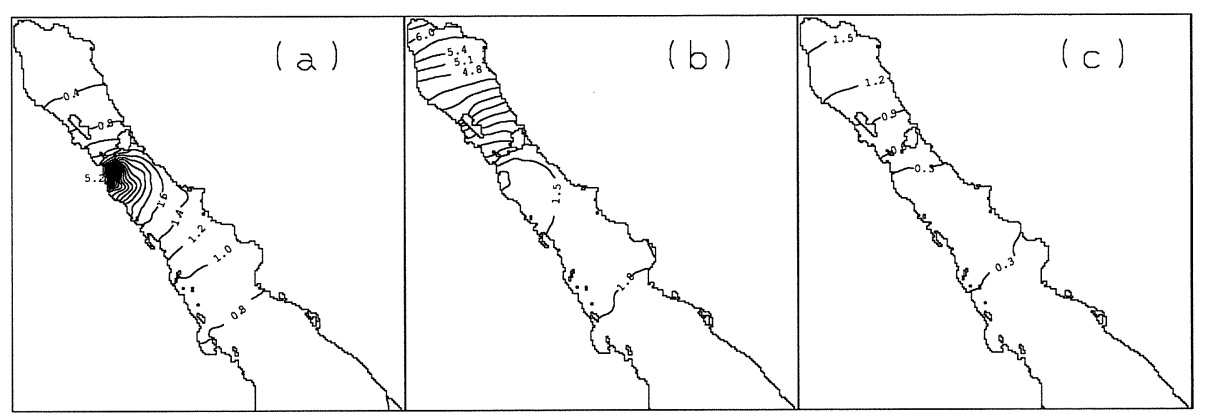

Figure 3. Characteristics of the tides in the Gulf of California, from the three-dimensional numerical model of Marinone (2003). (a) Form factor. (b) Tidal range (m) during spring tides. (c) Tidal range (m) during neap tides.

The tidal ellipses from barotropic models [for comparisons vs. observations, see Argote et al. (1995) and Marinone (2000)] are very rectilinear and mainly oriented along the length of the gulf. The orientation of the surface M2 tidal ellipses from the 3D baroclinic numerical model of Marinone (2003) is not very different from that of homogeneous models. In the SGC the M2 tidal currents are only a few $\mathrm{cms}^{-1}$, and they are strongest $\left(60 \mathrm{cms}^{-1}\right)$ in the archipelago and in the UGC. Tidal currents are fortnightly modulated (Badan-Dangon et al., 1991a; Marinone, 1997), and observations show important variations with depth (Ramírez Manguilar, 2000; Marinone, 2000; López and García, 2003; Jiménez Lagunes, 2003).

The fact that the amphidromic region is not in the center of Guaymas basin means that part of the semidiurnal tidal energy is lost by bottom friction in the northern part. The rate of energy dissipation by bottom friction of the M2 tidal constituent in the GC is around $4.3 \times 10^{9} \mathrm{~W}$, from tidal observations (Filloux, 1973). Calculations based on numerical models, made by several authors, range between 3 and $9 \times 10^{9} \mathrm{~W}$ for M2. Most of the dissipation occurs in the archipelago, especially over the sills, and in the UGC (Argote et al., 1995; Marinone, 1997; Carbajal and Backhaus, 1998; Marinone, 2000).

A fraction of the energy extracted from the tidal currents by bottom friction is used for vertical mixing, therefore tidal mixing is important in the areas where tidal dissipation is high: the UGC, the archipelago and the shelf south of Tiburón Island. Mixing can also occur in the interior of the fluid, by baroclinic processes, like breaking internal waves. Marinone and Lavín (this volume) find that there are conditions for strong internal mixing over the sills and in the surrounding area. Both internal and bottom mixing are tidally modulated, at the diurnal, semidiurnal and fortnightly frequencies, which cause variations in the distribution of sea surface temperature (SST) and stratification around the islands (Paden et al., 1991; Simpson et al., 
1994; Argote et al., 1995). The areas of strong tidal mixing are the most biologically productive of the GC (Alvarez-Borrego and Lara-Lara, 1991). Internal tides and solitons. As the tide passes over the sills the tidal currents accelerate, and internal hydraulic processes distort the thermocline (Paden et al., 1991) which causes part of the tidal energy to be radiated as internal waves. Filonov and Lavín (2003) reported the presence of semidiurnal, diurnal and quarterdiurnal internal tides, apparently propagating north from San Esteban sill. The semidiurnal internal tide is the most energetic ( 45 of the energy of the barotropic tide), with wavelengths of 10$40 \mathrm{~km}$ and phase speeds of $0.4-0.9 \mathrm{~ms}^{-1}$. The semidiurnal internal wave currents are aligned with the gulf axis and have amplitude of 0.10-0.15 $\mathrm{ms}^{-1}$. Jiménez-Lagunes (2003) found similar results for the semidiurnal and diurnal internal tides in the NGC, and also that inertial oscillations were generated by hurricane Nora in September 1997. The numerical models of Beier (1999) and Marinone (2003) show that internal tides are important enough to alter the smooth flow of the barotropic tide, which explains the apparently random orientation and sense of rotation of the observed M2 current ellipses in the NGC (Ramírez Manguilar, 2000; Marinone, 2000).

Also radiating from the sills are high-frequency soliton-like internal wave packets (Fu and Holt, 1984), with a 1-2 km wavelength, which travel along the thermocline in the same direction as the internal tides, at a speed of roughly $1.2 \mathrm{~ms}^{-1}$. They are generated over the sills mainly in spring tides, and carry an estimated 10 of the barotropic tidal energy. Direct observations of these solitons show vertical displacements of the isotherms of the order of 20-50 m with periods of 40-50 minutes (Badan-Dangon et al., 1991a; Gaxiola et al., 2002).

\section{Average and seasonal dynamics and thermodynamics}

The upper layers of the GC are strongly seasonal in circulation and in thermohaline structure (sea surface temperature and salinity, water masses, stored heat, surface mixed layer depth, etc.). This behavior is a response to the seasonality of the main forcing agents, namely: the Pacific Ocean, the wind system, and the fluxes of heat and moisture.

\subsection{FORCING AGENTS}

(i) The Pacific Ocean. The water masses around the entrance of the GC are moved by the ETPac system of oceanic currents, which have a strong seasonal behavior, a reflection of the meteorological seasonal changes at Pacific Ocean scale (Wyrtki, 1965, 1966; Baumgartner and Christensen, 1985; Fiedler, 1992; Strub and James, 2002a). The seasonal movement of the 


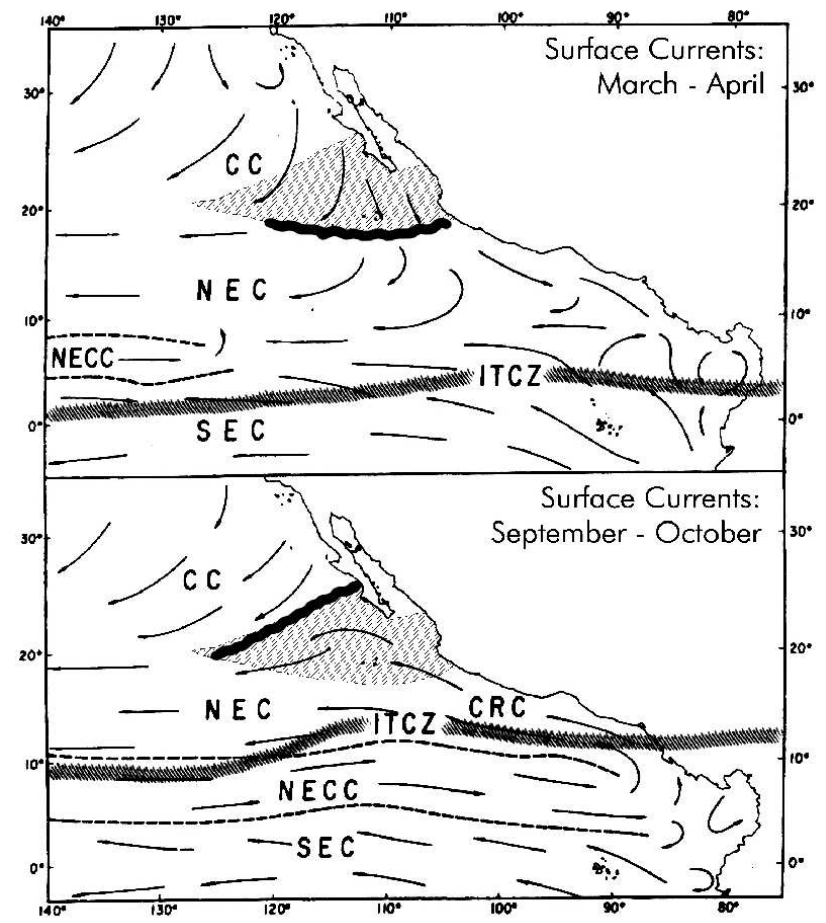

Figure 4. Surface currents in the Eastern Tropical Pacific in (a) March-April and (b) September-October. Arrows indicate the main surface currents: SEC= South Equatorial Current, $\mathrm{NECC}=$ North Equatorial Counter Current, $\mathrm{NEC}=$ North Equatorial Current, $\mathrm{CRC}=$ Costa Rica Current, $\mathrm{CC}=$ California Current. $\mathrm{ITCZ}=$ Inter-Tropical Convergence Zone. The limits of the California Current in (a) and (b) are marked by a wavy band. Based on Wyrtki (1965) and Baumgartner and Christensen (1985).

Inter-Tropical Convergence Zone (ITCZ) imposes latitudinal displacements of the equatorial current system (Figure 4), which determine in particular how far south the California Current will reach and how far north the Costa Rica Coastal Current will carry TSW (Wyrtki, 1967; Fiedler, 1992).

The sea level of the ETPac shows a seasonal signal, which has been identified in tide gauge data (Ripa, 1997) and in satellite altimeter data (Strub and James, 2002a). This seasonal signal moves toward the pole along the coast, from SW Mexico to Alaska (Strub and James, 2002a).

(ii) Wind. The wind in the GC has a marked seasonal behavior, product of the seasonal changes of atmospheric pressure centers in its vicinity and the channeling effect of the mountain chains in both sides: in autumn, winter and spring the wind blows from the NW with a speed of 8 to 12 $\mathrm{ms}^{-1}$, while in summer it blows from the SE with a mean speed of $\leq 5$ 
$\mathrm{ms}^{-1}$ (Roden, 1964; Badan-Dangon et al., 1991b; Merrifield and Winant, 1989; Badan, this volume). Recent wind velocity observations from the NSCAT and QuickScat satellite scatterometers (Parés et al., 2003) suggest that the summer reversals may not occur in the NGC and only for periods of a few days in the SGC, which would explain their absence in quarterly climatologies from ship reports (Fiedler, 1992).

(iii) Surface fluxes. Figure 5 shows the monthly means of heat fluxes in Guaymas basin and in the NGC calculated with bulk formulae (Castro et al., 1994). Marked seasonality is apparent in all cases, which is due to the seasonality of the meteorological and astronomical variables. Solar heating is the largest term, and the largest heat loss is due to evaporation, followed by long wave radiation. The annual fit to the surface heat flux for the entire GC (Castro et al., 1994) is

$$
Q_{s}=\{18+20 \cos (\omega t-\phi)\} \times 10^{12} W,
$$

where $\omega$ is the annual frequency and $\frac{\phi}{\omega}$ is June 9. The net heat flux $Q_{s}$ has, in addition to the seasonal cycle, two important features (Bray, 1988a; Lavín and Organista, 1988; Ripa and Marinone, 1989; Paden et al., 1993): (i) unlike other evaporative marginal seas, the GC gains heat through the surface in the annual mean, and (ii) there are net heat losses in the NGC in November and December.

Evaporation (E) is an important process in the GC, being responsible of the high salinity of the GCW. Precipitation (P) is negligible in the NGC and has a summer maximum in the southern part. The mean monthly values of E-P for the NGC, the archipelago and the SGC, present annual and semiannual variations (Roden, 1958; Ripa and Marinone, 1989; Romero Centeno, 1995; Beron-Vera and Ripa, 2002).

\subsection{THERMODYNAMICS}

(i) Heat balance. The heat balance for the GC, in the average and in the seasonal time scale, was first made by Castro et al. (1994) and in more detail by Beron-Vera and Ripa (2000). They used CICESE's hydrographic data bank to calculate the heat content of the GC in the upper $400 \mathrm{~m}, \mathcal{H}$ $=\int_{v} \rho c_{p} T d v$ where $V$ is the volume. The heat balance for the entire gulf is:

$$
\frac{\partial \mathcal{H}}{\partial t}=\mathcal{Q}_{s}+\mathcal{F}_{H},
$$

where $\mathcal{Q}_{s}$ is the surface heat flux and $\mathcal{F}_{H}$ is the heat flux through the mouth. Figure 6a shows the different terms of the heat balance (2). In average $18 \times 10^{12} \mathrm{~W}$ enter the gulf through the surface and exit trough the mouth. The seasonal variation is very large (larger than the mean), and 

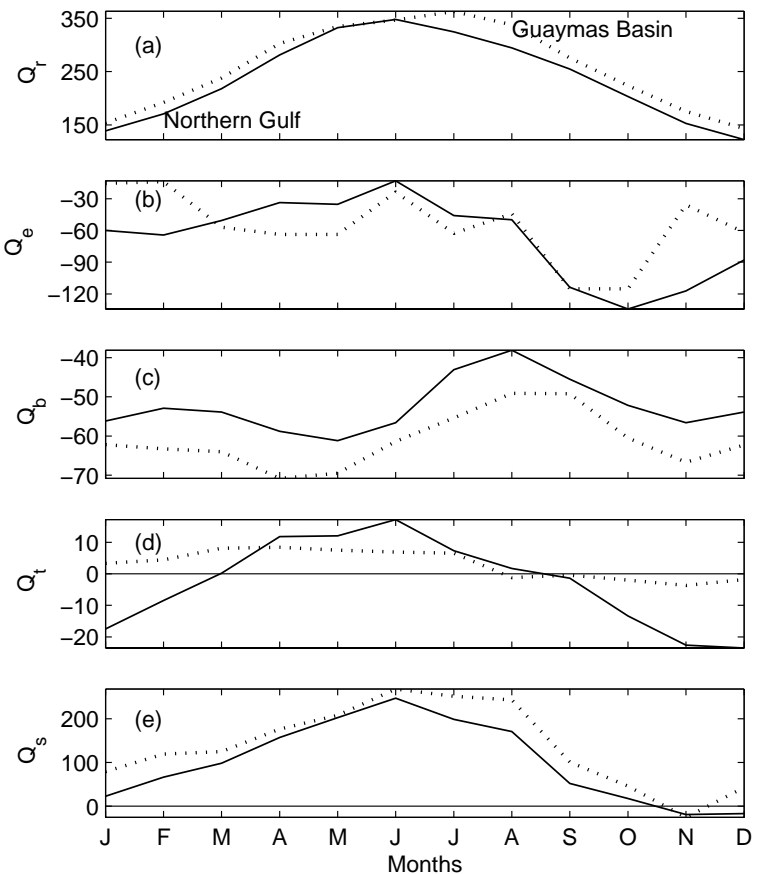

Figure 5. Monthly average surface heat fluxes (in $\mathrm{W} \mathrm{m}^{-2}$ ) in the NGC (continuous line) and in Guaymas basin (dotted). (a) Net short wave radiation, (b) Latent heat flux, (c) Back radiation, (d) Sensible heat flux, (e) Total surface heat flux. Data from Castro et al. (1994).

the amplitude of the seasonal horizontal heat flux is twice that through the surface. This means that the seasonal heat exchange between the GC and the PO is more important than the surface heat flux.

(ii) Salt balance. Following Beron-Vera and Ripa (2002), let $\langle\mathcal{S}\rangle=$ $V^{-1} \int_{v} S d v$ be the average salinity of the upper $400 \mathrm{~m}$ of the GC, where $V$ is the volume. Then the salt balance is

$$
\frac{\partial<\mathcal{S}>}{\partial t}=<\mathcal{S}>(\mathcal{E}-\mathcal{P})+\mathcal{F}_{S},
$$

where $\mathcal{E}-\mathcal{P}$ is evaporation minus precipitation and $\mathcal{F}_{S}$ is the salt flux through the mouth. Figure $6 \mathrm{~b}$ shows the different terms of equation (3). Although the uncertainties of this balance are larger than those for heat, it is found that the flux of salt through the mouth is more important than evaporation in controlling the mean salinity (Beron-Vera and Ripa, 2002). (iii) Sea level. The sea level in the GC has a seasonal variation, of amplitude $\sim 15 \mathrm{~cm}$ (Figure 7a), with maximum elevation in summer and minimum in winter. Although atmospheric pressure accounts for a little of this seasonal variation, most of it is due to changes in heat and salinity of the water 


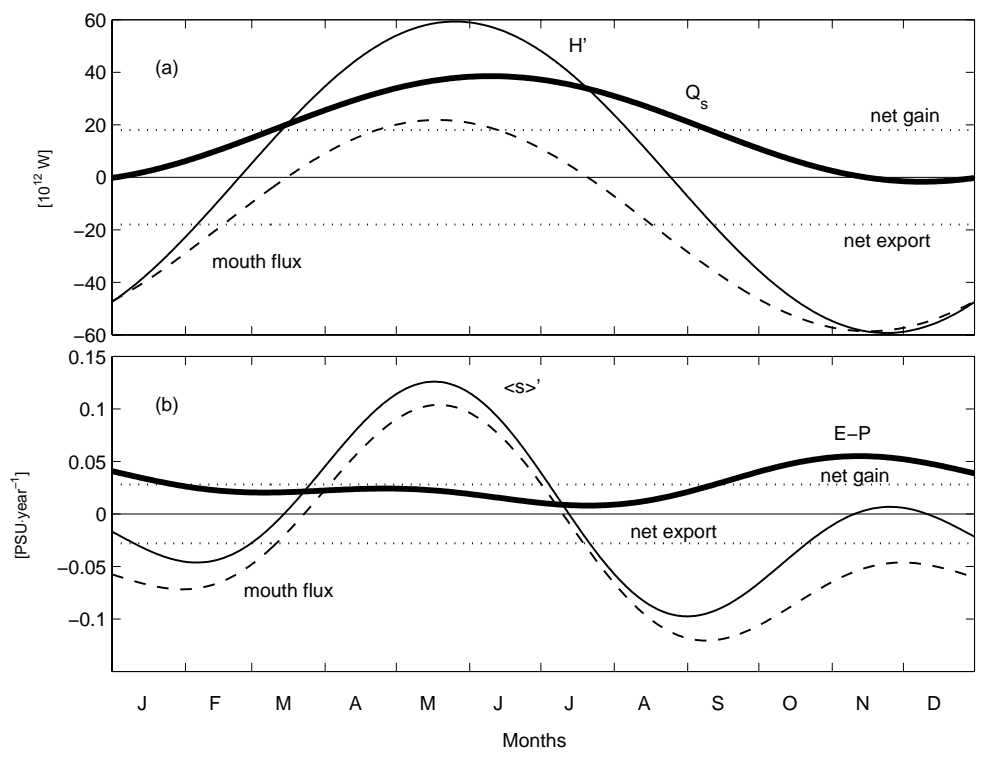

Figure 6. Overall Gulf of California mean and seasonal balances of (a) heat (after Castro et al., 1994), and (b) salt (after Beron-Vera and Ripa, 2002).

column (Roden and Groves, 1959; Ripa and Marinone, 1989; Ripa, 1990 and 1997). Therefore, in accordance with the heat and salinity balances, the seasonal sea level variation in the GC is mainly due to the fluxes of heat through the mouth. This is congruent with the PO forcing the seasonal sea level, and with the heat and salinity balances.

\subsection{CIRCULATION}

\subsubsection{Seasonal Circulation}

(i) Ripa's model. Figure 7a shows that there are differences in the amplitude and phase of the annual harmonic of the sea level in opposite sides of the GC. The sea level difference is a measure of the geostrophic velocity along the gulf, which is shown in Figure 7b (Ripa, 1997). The high correlation between sea level and geostrophic current apparent in Figure 7, and the lag between the two stations, suggest that there is an intrusion or perturbation forced at the mouth by the PO, which travels counterclockwise around the GC at $1.6 \mathrm{~ms}^{-1}$, which is approximately the phase speed of a first-mode baroclinic wave traveling in a two-layer channel similar to the gulf. The hypothesis that the seasonal forcing of the GC by the PO is in the form of a baroclinic internal Kelvin wave of annual period is due to Ripa (1990, 1997), who also proved that the hypothesis can explain the annual signals of sea level and heat content. This hypothesis suggested that the seasonal 

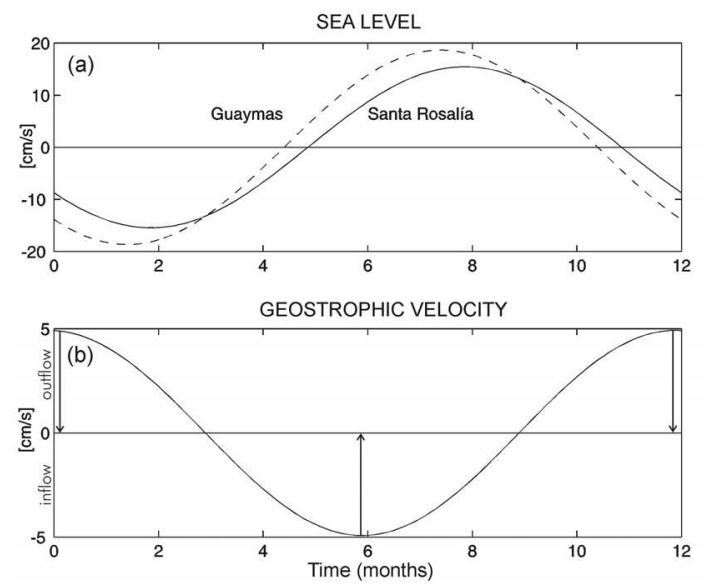

Figure 7. (a) Annual variation of the sea level in opposite sides of the Gulf of California: Guaymas in the mainland (dashed) and Santa Rosalía in the peninsula (solid). (b) Geostrophic velocity calculated from the difference in sea level between the two stations. Adapted from Ripa (1997).

circulation of the GC may be dominated by the PO, in a radical departure from the accepted idea that the wind was the main forcing agent (Roden and Groves, 1959; Bray, 1988a). The geostrophic circulation induced by this wave would be responsible for the seasonal signals of $\mathcal{F}_{S}$ and $\mathcal{F}_{H}$.

(ii) Observations. The first descriptions of the surface circulation in the GC, which were based on ship drift reports (U.S. Hydrographic Office, 1947; cited by Roden, 1958 and 1964), suggested influx in summer and outflow in winter, and a cause-effect relationship was suggested between the wind pattern and the surface circulation. The circulation pattern appeared to be supported and extended by the surface salinity distribution, which suggested that high salinity water (GCW) left the GC on the peninsula side and that its influence reached further in winter, while low-salinity water (TSW) was found entering the gulf along the eastern coast (Roden, 1964). Early geostrophic velocity calculations (Roden and Groves, 1959) also showed surface inflow in summer and outflow in winter.

The strength of the seasonal signal of geostrophic velocity, calculated from hydrographic data, was studied by Bray (1998a) for several crosssections along the length of the gulf and by Marinone and Ripa (1988) and Ripa and Marinone (1989) for the Guaymas basin. A clear seasonal signal was found for the surface transport (with inflow in summer and outflow in winter) and for the wind stress. While Ripa and Marinone (1989) found that the lateral and temporal variability of the geostrophic velocity in Guaymas basin was so large that the lateral structure could not be unraveled, Bray (1988a) found it weakly cyclonic in average, cyclonic in summer with speeds 
of 0.2 to $0.3 \mathrm{~ms}^{-1}$ and anticyclonic $\left(\sim 0.2 \mathrm{~ms}^{-1}\right)$ in spring and fall.

A similar study, but for the inner mouth of the gulf, has been carried out by Castro et al. (2000), Castro Valdez (2001) and Mascarenhas et al. (2003), but using closely-spaced CTD stations from nine surveys. Clear seasonal patterns are observed in the fields of temperature, salinity and geostrophic velocity. In average there is outgoing flux of salty GCW water close to the peninsula and ingoing flux of fresher water along the mainland coast. The seasonal signal of the geostrophic velocity (37\% of the variance) consists of a reversing pattern with inflow (outflow) in the central part and outflow (inflow) mostly on the peninsula side during May (September). The seasonal transports of heat and salinity calculated with these data are in good agreement with those estimated in the balances described above; this is a very important result, since it is an independent estimate of $\mathcal{F}_{S}$ and $\mathcal{F}_{H}$, and also gives support to the model of Ripa (1997), in that those fluxes are carried out by the geostrophic currents.

The seasonal circulation in the Northern Gulf is dominated by a seasonally reversing gyre, cyclonic from June to September and anticyclonic from November to April, with speed $0.35 \mathrm{~ms}^{-1}$ in both seasons; the transitions appear to last a couple of weeks. Direct evidence for this pattern was obtained from satellite-tracked drifters by Lavín et al. (1997a) and from current meter data by Palacios-Hernández et al. (2002). The corresponding hydrographic sections show that in summer the strong stratification is characterized by doming isolines, which leads to a low center in dynamic height and cyclonic geostrophic currents with surface speed comparable to that of the drifters, while in winter stratification is much weaker and the isolines are depressed in the center of the basin, which generates a high in dynamic topography. The persistence of the pattern has been proved by Bray (1988a) and Carrillo et al. (2002) from geostrophic calculations using hydrographic data banks, and from 14 years of AVHRR data by Soto-Mardones et al. (1999).

In winter the geostrophic speed is lower than that of the drifters or the current meters, which means that at least in winter the gyre is partly barotropic and partly baroclinic. The barotropic component appears to be caused by the interaction of the annual internal wave with the bathymetry and the coastline (Beier and Ripa, 1999).

(iii) Numerical models. Ripa (1997) used an analytical, linear, two-layer box model to illustrate the individual effects of the three forcing agents: the Pacific Ocean, the wind and the surface heat flux $\left(\mathrm{Q}_{s}\right)$, and to justify the applicability of a laterally-averaged model with laterally-averaged topography. The PO forcing is simulated as an internal Kelvin wave of annual period, trapped within an internal Rossby Radius $(30 \mathrm{~km})$, the wind was simulated by a seasonal cycle with NW winds in winter and SE winds in 
summer, with maximum speeds of $5 \mathrm{~ms}^{-1}$ up-gulf in August, and $\mathrm{Q}_{s}$ was specified from Castro et al. (1994). The seasonal cycle of sea level and the seasonal heat balance are well reproduced. The contributions of the PO, the wind and $\mathrm{Q}_{s}$ to the seasonal sea level variability are $6.6 \mathrm{~cm}, 2.9 \mathrm{~cm}$ and $0.9 \mathrm{~cm}$, respectively. The annual amplitude of the laterally-averaged geostrophic velocity is made up of $2.9 \mathrm{cms}^{-1}$ from the PO, $1.0 \mathrm{cms}^{-1}$ from the wind and $0.3 \mathrm{cms}^{-1}$ from $\mathrm{Q}_{s}$. The seasonal heat flux through the mouth is given by $33 \mathrm{TW}$ from the PO, $10 \mathrm{TW}$ from the wind and $3 \mathrm{TW}$ from $\mathrm{Q}_{s}$ $\left(1 \mathrm{TW}=10^{12}\right.$ Watts $)$. The conclusion is that the seasonal thermodynamics and circulation are not dominated by local processes (wind and $\mathrm{Q}_{s}$ ), but driven by the Pacific Ocean.

The lateral structure of the circulation induced by the same three forcings was studied by Beier (1997) with a linear two-dimensional, two-layer baroclinic model with a $70 \mathrm{~m}$ thick surface layer and real topography. It is found that the wind also generates an internal Kelvin wave, with amplitude increasing toward the interior of the gulf. The results reproduce the seasonal sea level variation, and give support to the findings of Ripa (1997) regarding the relative importance of the forcing agents. Details of the lateral structure of the circulation are also obtained: the seasonally-reversing gyre in the NGC is reproduced, and in the SGC there is anticyclonic surface circulation in winter and a cyclonic circulation in summer. A non-linear, vertically-entraining version of the model was used by Beier (1999) and Palacios-Hernández et al. (2002) to demonstrate that the difference in stratification due to winter mixing is a possible cause for the inequality in the duration of the cyclonic and anticyclonic regimes in the NGC. The simulated seasonal circulation and sea surface temperatures are closer to observations than the model of Beier (1997). This was the first non-linear baroclinic model of the GC that included vertical mixing.

A 3D non-linear numerical model of the seasonal circulation and thermodynamics of the $\mathrm{GC}$ with real topography and vertical and lateral mixing has been developed by Marinone (2003) (for more details, see Marinone and Lavín, this volume). While the same sinusoidal seasonal wind is used, the other forcings differ in important ways from those used by Ripa (1997) and Beier (1997, 1999): (a) At the mouth the sea surface elevation is prescribed at tidal (7 harmonics), annual and semiannual frequencies. (b) Observations are used to specify the annual and semiannual variations of the temperature and salinity fields at the mouth cross-section. (c) At the surface, heat and fresh water fluxes were calculated with the model SST and bulk formulae using seasonally-fitted meteorological data.

This model reproduces the annual and semiannual variability of sea level, the balances of heat and salt, and the climatology of the sea surface temperature. In Figure 8 the surface currents predicted by the run with all 


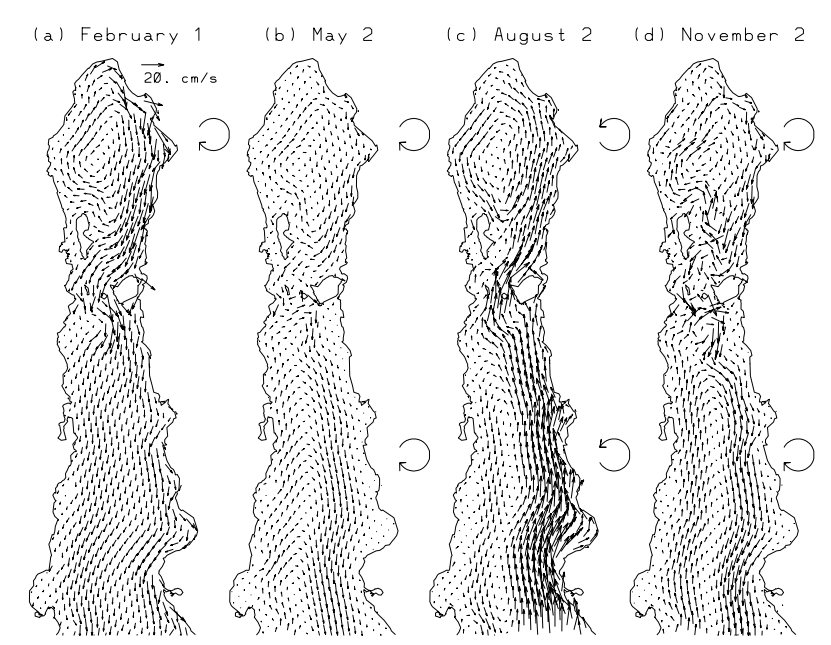

Figure 8. Residual currents for the surface layer $(0-10 \mathrm{~m})$ from the 3D model of Marinone (2003), for (a) February 1, (b) May 2, (c) August 2 and (d) November 2. The scale arrow is shown in (a). The gyres on the right of each panel are visual aids indicating the overall sense of rotation in the different sections of the gulf.

the forcings are shown for dates representative of the circulation regimes observed. The seasonally-reversing gyre in the northern GC is obtained. In the Ekman layer in the SGC, one cyclonic period occurs in August, while there are two anticyclonic periods, in May and November. In deeper layers (Marinone, 2003) the circulation is cyclonic during winter and summer, and anticyclonic during autumn and spring. The annual average surface current is shown in Figure 9a, and the first two modes of an Empirical Orthogonal Function (EOF) analysis of the surface circulation is shown in Figures 9b,c,d. The first mode shows a strong annual signal, with anticyclonic surface circulation from June to September, and cyclonic from October to April; this mode is asymmetrical, with strong currents on the mainland side and weak currents on the peninsula side (Figure 9b,d). In the SGC the surface circulation is due to both, the PO and the wind, and it presents a semiannual variability, captured by mode 2 (Figures $9 \mathrm{c}, \mathrm{d}$ ). Therefore the modelled seasonal circulation in the SGC seems to reflect the forcing functions used at the mouth; annual in Beier (1999) and annual plus semiannual in Marinone (2003).

\subsubsection{Annual Average Circulation}

The annual-mean circulation of the GC has been obtained from non-linear models by Beier (1999) and Marinone (2003). The surface circulation predicted by the model of Marinone (2003), shown in Figure 9a, presents an anticyclonic gyre covering the entire NGC, a cyclonic gyre north of Ángel 


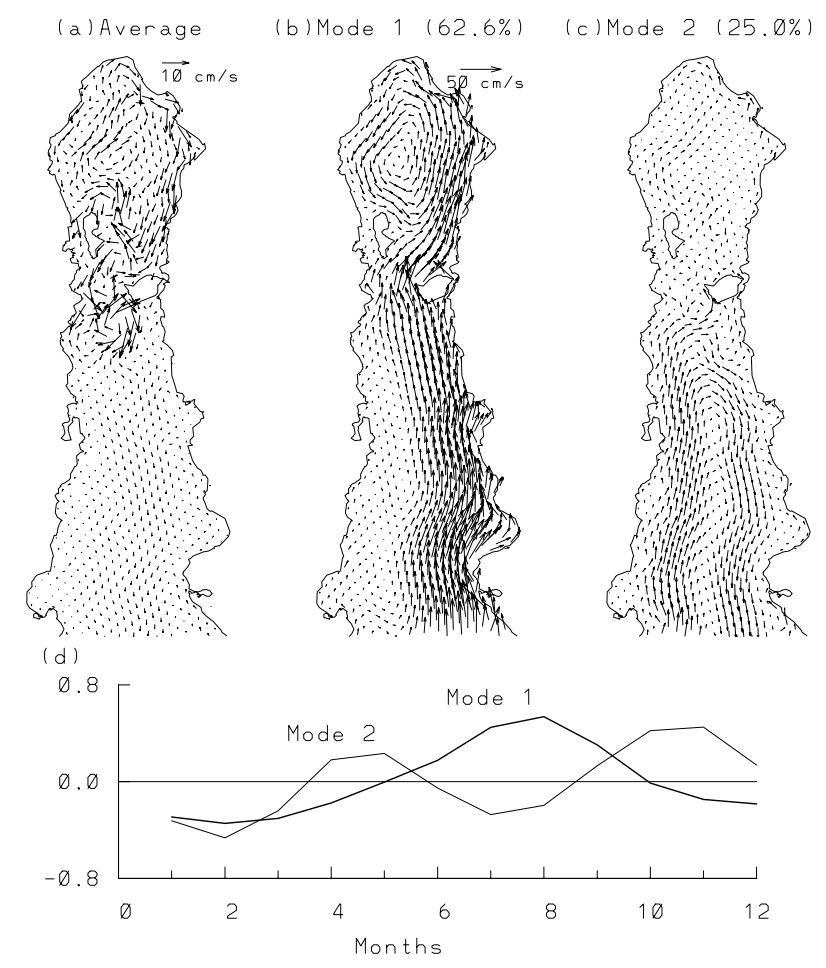

Figure 9. Surface velocity mean and seasonal patterns, from the 3D numerical model of Marinone (2003). (a) Average surface circulation for the surface layer (0-10 m). (b) and (c) Spatial distribution of the first and second EOF modes, respectively. (d) Time variation of the first (thick line) and second modes (thin line). Note that the scale arrows are different for the average and the EOF modes.

de la Guarda island, and anticyclonic circulation south of the San Esteban island. In the SGC a weak outflowing current is present away from the coasts. A net surface outflow from the NGC occurs through the archipelago, which is compensated by a permanent inflow close to the bottom over San Esteban sill (Marinone, 2003; Marinone and Lavín, this volume). A similar mean circulation pattern was obtained with the two-layer non-linear numerical model of Beier (1999), who notes that the two-layer vertical structure is driven by vertical mixing.

The across-gulf average of Figure 9a, shown in Figure 10, produces a two-layer flow. Outflow takes place in the upper layer, which is $200 \mathrm{~m}$ thick in the SGC and shallows to $50 \mathrm{~m}$ in the NGC. The maximum outflow $\left(0.02-0.03 \mathrm{~ms}^{-1}\right)$ occurs above the sills, centered in a depth of $100 \mathrm{~m}$. Compensating inflow occurs in the rest of the water column, with maximum speeds $\left(0.02-0.03 \mathrm{~ms}^{-1}\right)$ above the sills. This residual flow is responsible of exporting the average surface heat gain and the average excess salt 

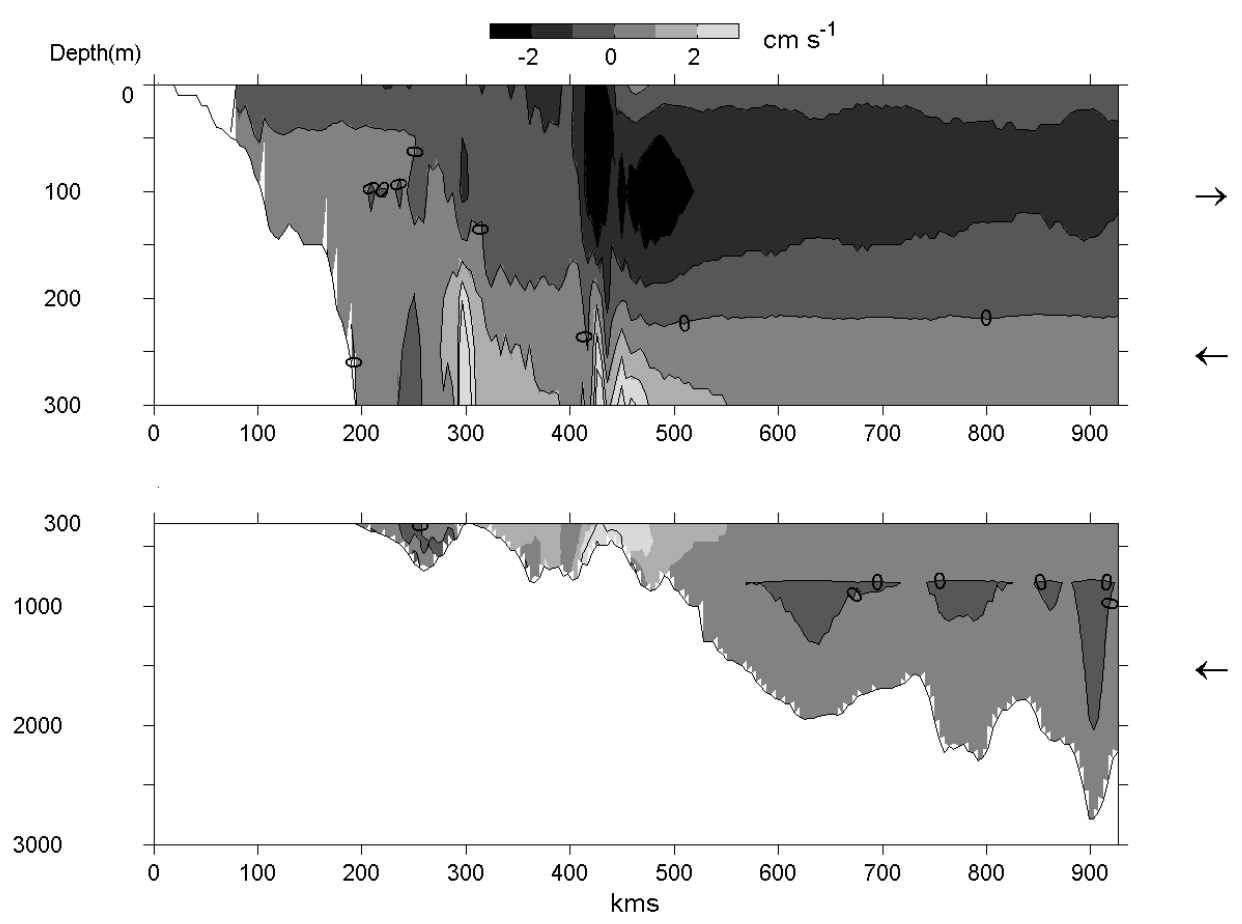

Figure 10. Laterally-averaged residual circulation for the 3D model of Marinone (2003). The top panel shows the upper $300 \mathrm{~m}$, and the bottom panel from $300 \mathrm{~m}$ to the bottom. Speed palette on the top of the figure; positive values are into the GC, negative values are out of the GC. The arrows on the right are visual aids indicating the current direction.

apparent in Figure 6. The seasonal behavior of the laterally-averaged flow, described by Marinone (2003), includes a 20-50 m thick seasonally-reversing surface layer which flows in the same direction as the wind; the scheme is practically the same as the three-layer system proposed by Bray (1988a). However, care must be taken when interpreting this for the SGC, because its surface seasonal circulation is in opposite directions on the two sides of the gulf (Figure 8). The two-layer residual flow pattern is supported by direct current measurements in the sill between the Tiburón and Delfín basins, where a strong $\left(0.27 \mathrm{~ms}^{-1}\right)$ inflowing bottom current transporting an average of $0.1 \times 10^{6} \mathrm{~m}^{3} \mathrm{~s}^{-1}$ was observed by (López and García, 2003). Tidal Residuals. Tidal residual currents in barotropic models are produced by non-linear interaction of the tidal current with the bathymetry, especially in areas where the tidal excursion is comparable to the scale of bathymetric features and around points and capes; for the GC the process has been studied numerically by Marinone (1997), Argote et al. (1998), and Carbajal and Backhaus (1998), among others. The tidal residuals for the $10 \mathrm{~m}$ thick surface layer produced by the 3D numerical model of Marinone 

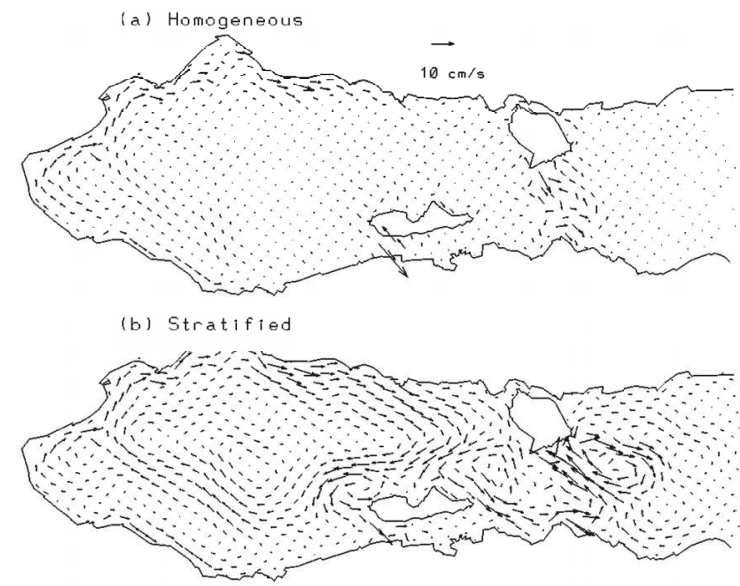

Figure 11. Tidal residual currents for the surface layer $(0-10 \mathrm{~m})$ from the $3 \mathrm{D}$ numerical model of Marinone (2003), forced with tides only. (a) Homogeneous. (b) Stratified.

(2003), without stratification and forced only with the 7 main tidal harmonics (Figure 11a) show an anticyclonic circulation in the NGC and the UGC, down-gulf coastal currents in the mainland coast of the NGC and in part of the peninsula coast. The speeds are $0.01-0.05 \mathrm{~ms}^{-1}$. In the SGC tidal residual currents are negligible.

In a stratified model with vertical mixing, the generation of residual currents is much more complex. In addition to the interaction of barotropic and internal tides with the bathymetry and with the residual currents, vertical mixing can rearrange the density field, and the resulting pressure gradients induce residual currents, some of which may become geostrophic. The thermal fronts created by tidal mixing in the NGC and around the archipelago (Argote et al., 1995) are a case in point. Figure 11b shows the residual currents for the $10 \mathrm{~m}$ thick surface layer from a model run with only the tidal forcing, but with the same initial stratification as the run with all the forcings (Marinone, 2003): in the archipelago and the NGC the residual currents are stronger $\left(0.1 \mathrm{~ms}^{-1}\right)$ than in the homogeneous case, and there is more lateral structure. This structure is similar to that of Figure 9a, the mean residual currents from the model run with all the forcing agents. The lateral average of the 3D annual-mean tidal residual current field produces a distribution very similar to Figure 10, which suggests that the annual mean residual flow field is induced by the tides, most likely through tidal mixing (Marinone, 2003).

Thermohaline circulation. The ocean circulation that results exclusively from the surface fluxes of heat and moisture is called thermohaline circulation. Despite high evaporation, the expected annual-mean thermohaline 
circulation in the GC is "inverse Mediterranean" (Bray, 1988a), because of the annual-mean gain of heat through the surface. Three-dimensional modelling of this process in isolation by Marinone (2003) produce currents that are one order of magnitude smaller than those shown in Figure 10. The three-layer system proposed by Bray (1988a) came from geostrophic transport profiles in Guaymas basin, and therefore represents the general geostrophic circulation, not only the thermohaline circulation. The three-layer system obtained by Marinone (2003) (Figure 10) seems to be tidally-induced; it is not obvious if they are the same. More realistic surface forcing functions may be necessary to study this subject, but the role of vertical mixing in the mean circulation and thermodynamics seems to be very important.

\section{Mesoscale Oceanography}

\subsection{THE ENTRANCE ZONE}

The line from the tip of the Baja California peninsula to Cabo Corrientes is the physical entrance to the GC. However, in most of the recent observational and modelling work the shorter line from the tip of the peninsula to El Dorado in the mainland is used. The main thermohaline characteristic of this province is its transitional character (Griffiths, 1968; Stevenson, 1970; Roden, 1971 and 1972). As suggested by the shaded area in Figure 4, the southern reach of the CC passes the area seasonally, and three surface water masses (TSW, CCW and GCW) intermingle among themselves in the top 150-200 $\mathrm{m}$ and with the upper layers of the StSsW immediately below.

In the inner mouth, the GCW is usually found as surface or subsurface layers or cores of high salinity in the upper $100 \mathrm{~m}$. These cores are most frequently found adjacent to the peninsula, but they have also been detected on the mainland side (Roden and Groves, 1959; Roden, 1971; Castro et al., 2000). The distribution of salinity across the inner mouth in December 1993 (Fig. 12a) illustrates the spatial variability of the distribution of the water masses in this area. According to the classification of Torres Orozco (1993), Figure 12 shows the GCW as $20 \mathrm{~m}$ thick layers, under the surface on the western side and on the surface on the eastern side, embedded in a surface layer of TSW. This TSW layer occupies most of the upper $50 \mathrm{~m}$ across the section up to $60 \mathrm{~km}$ west of the peninsula. From 80 to $400 \mathrm{~m}$ depth, there is $\mathrm{StSsW}$, and the salinity around 34.85 at a depth of $150 \mathrm{~m}$ is probably the remains of the core of the StSsW, whose maximum has been lost due to the presence of the GCW. At 600 to $800 \mathrm{~m}$ there is a salinity minimum under 34.55, which is the core of the PIW.

The annual average hydrography across the inner mouth, obtained by Castro Valdez (2001) from a series of 9 high definition cross-sections (Fig- 


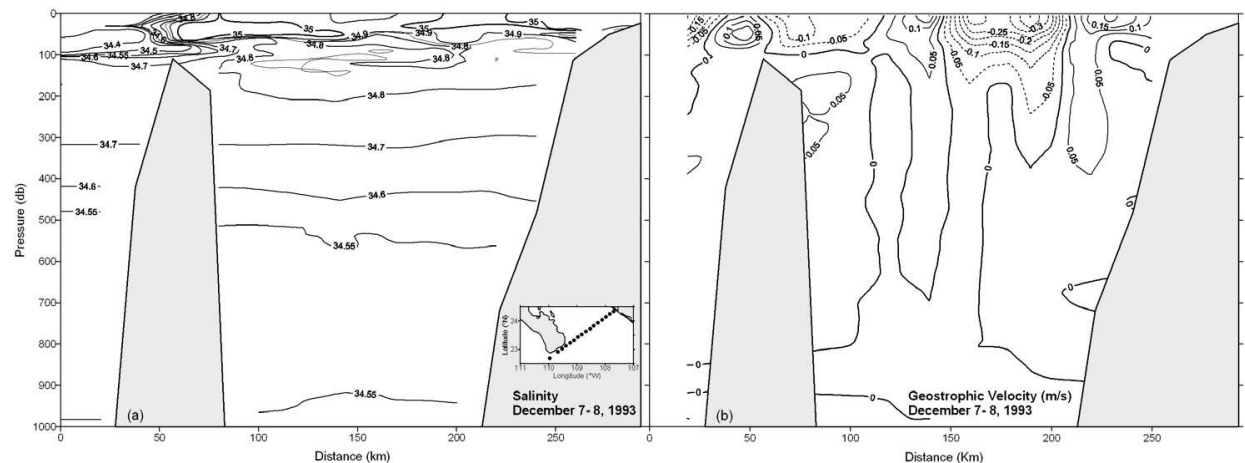

Figure 12. Vertical sections of (a) salinity and (b) geostrophic velocity across the inner mouth in December 1993. The peninsula is on the left side. In (b), common depth between adjacent stations was used as reference; negative values (dashed) indicate flow out of the gulf. No data below $1000 \mathrm{~m}$; maximum bottom depth in this section is $3000 \mathrm{~m}$. A map with the stations is shown in the inset in (a). Data from Godínez et al. (2001).

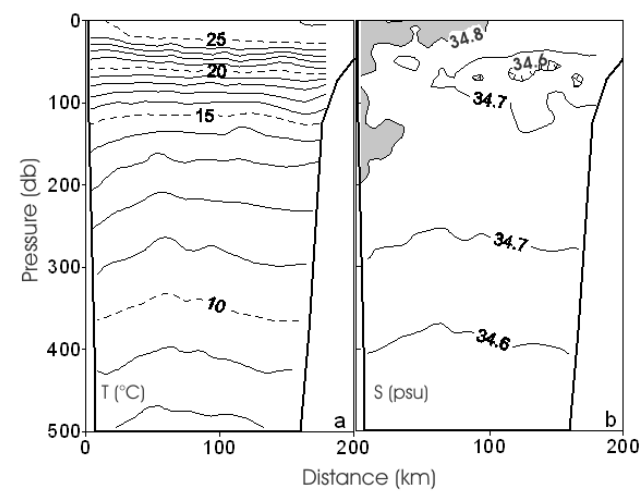

Figure 13. Average distribution of salinity across the inner mouth, from nine high-resolution surveys made form 1992 to 1998. After Castro Valdez (2001); Figure provided by R. Castro.

ure 13), shows that in the mean, the GCW is found as two narrow ( $40 \mathrm{~km})$ cores attached to the peninsula, one in the surface and another between 100 and $200 \mathrm{~m}$. On the mainland side the TSW is also concentrated around a core of fresher water.

Very high lateral variability is also found in the geostrophic velocity across the inner mouth, with gyres of length scales from 20 to $100 \mathrm{~km}$ and speeds around $0.1 \mathrm{~ms}^{-1}$ at depths exceeding $1000 \mathrm{~m}$ (Roden, 1971; Collins et al., 1997; Castro Valdez, 2001; Mascarenhas et al., 2003). The lateral variability is evident in the geostrophic velocity across the inner mouth in December 1993, Figure 12b, with alternating inflowing and outflowing 
regions in the upper $100 \mathrm{~m}$. The maximum depth in these observations is only $1000 \mathrm{~m}$, therefore the deep currents were not detected.

In addition to an average outgoing flux close to the peninsula and ingoing flux along the mainland coast, Mascarenhas et al. (2003) find a smaller anticyclonic circulation in the center of the inner mouth. The extent of the variability is reflected in only $37 \%$ of the variance being due to the seasonal cycle, which consists of a reversing pattern with inflow (outflow) in the central part and outflow (inflow) mostly on the peninsula side during May (September) (Mascarenhas et al., 2003).

The hydrography in the inner mouth has a clear seasonal cycle (Torres Orozco, 1993), especially in temperature and in mixed layer depth (Castro et al., 2000), which varies from $10 \mathrm{~m}$ in summer to around $40 \mathrm{~m}$ in winter. A dome is often observed in the deep isotherms across the inner mouth, which is associated to the deep currents and suggests the presence of a gyre (Collins et al., 1997; Mascarenhas et al., 2003). Drastic anomalies occur during El Niño, which consist of deepening of the surface mixed layer and the thermocline up to $50 \mathrm{~m}$ from their normal position, an increase in surface temperature of up to $4{ }^{\circ} \mathrm{C}$ and a decrease in salinity (0.1-0.2), caused by en extensive invasion of TSW (Lavín et al., 1997b; Castro et al., 2000).

The AVHRR satellite images of this area frequently show the presence of mesoscale gyres, made visible by the temperature contrast between the water masses. More about these gyres below.

\subsection{THE SOUTHERN GULF OF CALIFORNIA}

In the SGC, the GCW occupies the upper $100 \mathrm{~m}$, the salinity maximum of the StSsW is not discernible, and the salinity minimum of the PIW is slightly lower than in the mouth (Alvarez-Borrego and Schwartzlose, 1979; Robles and Marinone, 1987). Although the distribution of the water masses in the SGC is not as complicated as in the inner mouth, its dynamics is very rich in features.

Upwelling. The wind pattern described above is appropriate for the generation of upwelling, on the mainland coast in winter and on the peninsula in summer. Satellite images, however, only show clearly the winter upwelling on the mainland. It is not clear why the summer upwelling is weaker, but one possible reason is the weakness of the summer winds (Badan, this volume). There are no direct observational studies of upwelling in the GC, although satellite imagery (AVHRR and CZCS) has been used in their study (BadanDangon et al., 1985; Santamaría-del-Angel et al., 1994; LLuch-Cota, 2000). Roden (1964) and Carbajal (1993) estimated a mean upwelling rate for the GC of 1 to 3 meters per day. 
Geostrophic gyres. Satellite images of the SGC (AVHRR and color) often show a series of gyres about 50-150 km in diameter (Badan-Dangon et al., 1985; Pegau et al., 2002; Navarro-Olache et al., 2003). Their estimated tangential velocity is 25 to $40 \mathrm{cms}^{-1}$ (Emilsson and Alatorre, 1997; Pegau et al., 2002). No study of their life span has been conducted, but there is evidence that the largest ones are geostrophic and reach to over $1500 \mathrm{~m}$ in depth; they can be cyclonic or anticyclonic, but no seasonal pattern can be detected with the available hydrographic data (Figueroa et al., this volume). These large gyres are a very important ingredient of the circulation of the GC and probably dominate it at the mesoscale in the offshore region. The only direct measurements of their velocity are those by Emilsson and Alatorre (1997), and maybe the deep currents observed by Collins et al. (1997) and Mascarenhas et al. (2003) across the inner mouth are due to the presence of gyres of this kind. These gyres do not appear in the baroclinic models of Beier (1997) and Marinone (2003), which are forced by horizontally homogeneous seasonal winds. The first numerical model to produce them is the 3D model of Martínez Alcalá (2002), which uses nonhomogeneous, short-term variable winds measured by satellite (NSCAT); the seasonal cycle was not modelled, but the circulation pattern is rich in gyres. These gyres probably have a very important effect on the mean and seasonal circulation and thermodynamics, but the subject has not yet been studied.

Filaments and plumes. Also first observed in satellite images, there are in the GC many smaller-scale features like jets, filaments and plumes, which have a shorter life-span than the gyres (Badan-Dangon et al., 1985; Pegau et al., 2002). They seem to be associated to the basin-wide gyres (appearing on their edges), to wind-induced upwelling and to the thermal fronts induced by tidal mixing over the sills in the archipelago. Like elsewhere, they often occur on the lee of topographic features such as capes, from which they seem to originate. One of these jets, originating north of Guaymas basin from the tidal-mixing zone, was investigated with closely-sampled XBT and CTD stations by Navarro-Olache et al. (2003). It was a shallow feature (around $80 \mathrm{~m}$ deep), about $30 \mathrm{~km}$ wide, with speeds $\sim 0.5 \mathrm{~ms}^{-1}$ and a transport around $0.5 \times 10^{6} \mathrm{~m}^{3} \mathrm{~s}^{-1}$. This particular feature lasted some 10 days and stretched for more that $110 \mathrm{~km}$ before decaying.

Coastal trapped waves. During summer, the currents in the continental shelf of the SGC are not correlated with the local winds, because internal coastal-trapped waves (CTWs) dominate the velocity variability in scales of several days (Merrifield and Winant, 1989). These CTWs are generated by hurricanes in the ETPac (Christensen at al., 1983; Enfield and Allen, 1983; Zamudio et al., 2002) and travel inside the GC at 150-300 km per day. They are a hybrid of Kelvin and topographic continental shelf waves, 
and are usually isolated elevations of the sea surface with amplitudes $~ 10$ to $30 \mathrm{~cm}$, and corresponding depressions of the thermocline of 40 to $60 \mathrm{~m}$. The observations of Merrifield and Winant (1989) show currents as fast as $0.5 \mathrm{~ms}^{-1}$ in water $100 \mathrm{~m}$ deep associated to a $20 \mathrm{~cm}$ elevation CTW.

Insight into the behavior and consequences of the CTWs inside the GC is provided by the numerical modeling work of Martínez and Allen (2003a, 2003b). They show that the CTWs travel unhindered along the mainland coast, but upon reaching the archipelago, they split into two waves; one of them enters the NGC and is dissipated there, while the other turns west and returns along the peninsula coast. The returning CTW looses $50 \%$ of its amplitude around the sill, and the CTW that enters the NGC carries $10-20 \%$ of the incident energy. Most of the dissipation occurs in the sills. The strong nonlinearity of these waves cause partial breaking and a transfer of energy to the bottom of the deep basins.

The mechanism behind the hypothesis of Ripa (1997) that the seasonal lateral heat flux in the GC is due to an internal Kelvin wave (of annual period) is illustrated by Figure 8 of Martínez and Allen (2003a). It shows that on the mainland shelf the currents under an elevation CTW are directed into the gulf, and there is no (or little) return flow after it has passed. This causes a net flux of properties into the GC.

\subsection{THE ARCHIPELAGO}

The archipelago contains several sills and narrow channels or straits (Figure 1). Its most distinctive oceanographic characteristic is the presence of extensive and strong tidal mixing both by bottom friction and by internal instabilities (Argote et al., 1995; Marinone and Lavín, this volume). As the tide squeezes through the straits, tidal currents are intensified to such an extent that the flow may become supercritical (Badan-Dangon et al., 1991a), leading to turbulence so intense that surface boils can be seen in waters hundreds of meters deep. The upwelled water being colder than the surroundings, the area is highlighted in AVHRR images of the gulf; the lowest SST in the GC is found in this area throughout the year (BadanDangon et al., 1985; Paden et al., 1991). The overall distribution and the temporal and spatial variability of the SST in the area north of Guaymas basin is controlled by tidal mixing in the presence of the seasonal heat flux (Paden et al., 1991; Argote et al., 1995). Paden et al. (1991 and 1993) suggested that tidal mixing may be responsible for the net surface heat gain, by inhibiting latent heat flux via the low SST; indeed Ballenas channel is the area to the north of Guaymas basin where the least evaporation occurs and therefore the most heat is gained (Paden et al., 1993; Romero Centeno, 1995). 


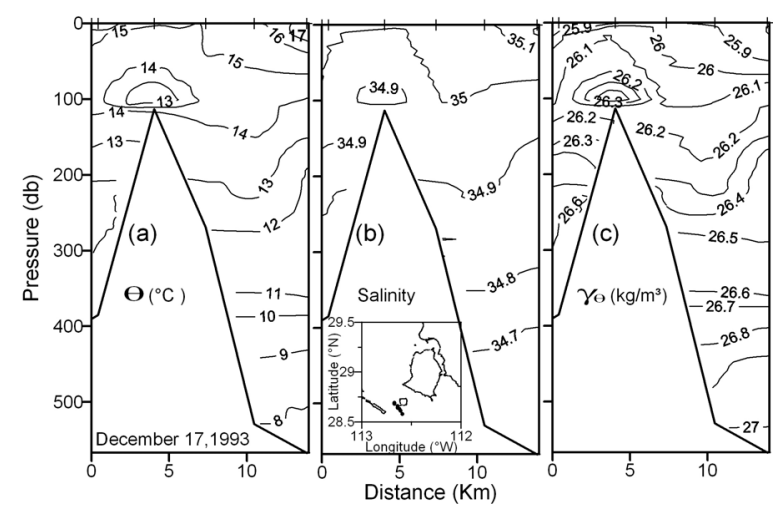

Figure 14. Vertical hydrographic sections along San Esteban channel in December, 1993: (a) potential temperature, (b) salinity, (c) density anomaly. A map with the position of the stations is shown in the inset.

Figure 14 shows vertical sections of temperature, salinity and density anomaly along San Esteban channel made in December, 1993. The isolines present vertical distortions over $100 \mathrm{~m}$, which are part of the generation mechanism of internal tides. There are also thermal and haline surface fronts where the isolines break into the surface. The GCW ( $\mathrm{S} \geq 35)$ occupies the upper $100 \mathrm{~m}$, and underneath only StSsW is present. The effect of tidal mixing in lowering the SST can extend some $400 \mathrm{~km}$ to the south of the archipelago (Navarro-Olache et al., 2003), and probably all over the NGC (Paden et al., 1991).

The Ballenas channel is very deep (maximum $1600 \mathrm{~m}$ ), and has sills both to the north (600 m deep) and south (400 m deep), which give it such unique characteristics that it can be considered an oceanographic province in itself. The water below $600 \mathrm{~m}$ in Ballenas channel has a temperature of $11^{\circ} \mathrm{C}$ and a salinity of 34.8. The deep water in Ballenas channel is well aired (Alvarez-Borrego and Schwartzlose, 1979), which indicates that the residence time is not long.

The interchange of water between the northern and the southern parts of the gulf takes place through the straits of the archipelago. The StSsW that enters to the NGC below 100-150 m is transformed into GCW and then exits in the upper layers. The best communication is through San Esteban Channel, between San Lorenzo and San Esteban islands, because of its depth $(600 \mathrm{~m})$ and width. The San Lorenzo channel is $200 \mathrm{~m}$ shallower at the threshold than San Esteban channel and very narrow. The channel between San Esteban and Tiburón islands reaches $500 \mathrm{~m}$ in depth but is isolated from the SGC below $\sim 350 \mathrm{~m}$ by a ridge extending east from San Esteban island. The Infiernillo channel, between Tiburón island and the 


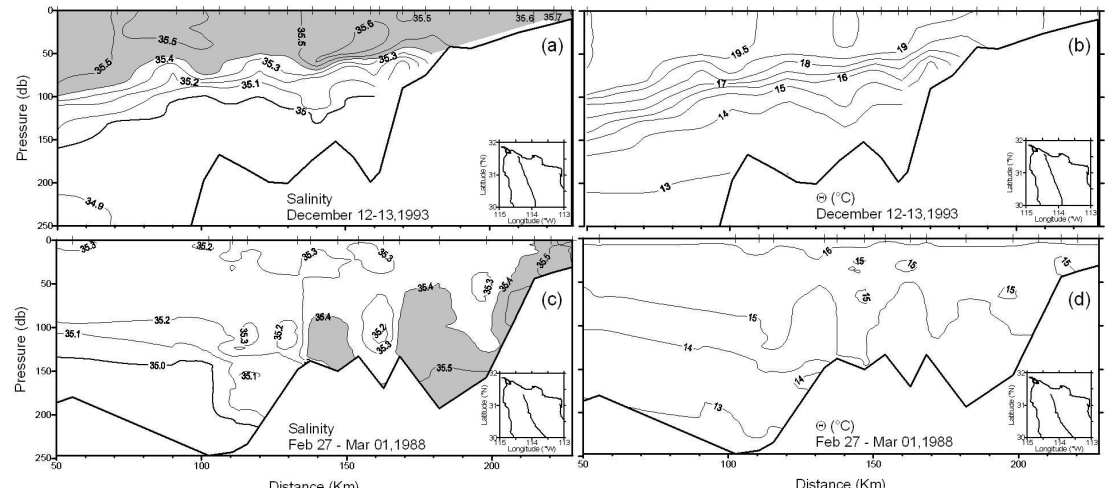

Figure 15. Temperature and salinity sections in the NGC in (a and b) December 12-13, 1993, and (c and d) February 27-March 1, 1988.

mainland is only $5 m$ deep. The flow of StSsW into the NGC has been measured with current meters located right on the thresholds: in San Lorenzo sill by Badan-Dangon et al. (1991a) for a couple of weeks, in the sill between Tiburón basin and Delfín basin for several months by López and García (2003), and in San Lorenzo sill for over one year by M.L. Argote (Pers. Comm.); they have all found strong ( 0.3 to $0.5 \mathrm{~ms}^{-1}$ ) inflowing currents close to the bottom and weaker outflow in the upper layers.

\subsection{THE NORTHERN GULF OF CALIFORNIA}

The water mass distribution in the NGC consists of GCW in the top 150 $\mathrm{m}$ and StSsW underneath (Torres Orozco, 1993; Romero Centeno, 1995). Vertically homogeneous conditions exist in the northernmost fringes of the NGC, down to the $30 \mathrm{~m}$ isobath in summer and down to $60 \mathrm{~m}$ in winter; the position of the front is imposed in summer by tidal mixing and in winter by tidal mixing and vertical convection (Argote et al., 1995). The salinity (S) and temperature (T) distributions in December of 1993 (Figures 15a,b) show the GCW in the top 100-150 m and the StSsW below. There is a surface mixed layer $\left(\mathrm{S} \sim 35.5, \mathrm{~T} \sim 19.5{ }^{\circ} \mathrm{C}\right)$ that is $100 \mathrm{~m}$ deep in Delfín basin and shallows to $50 \mathrm{~m}$ in the northern edge of Wagner basin, where the thermocline ends as a bottom front. The hydrographic structure in late February-early March 1988 (Figures 15c,d) show a case when the saltiest water is found in the bottom of Wagner basin, evidence that the GCW has gone through vertical convection (Lavín et al., 1995).

The subsequent movement of the convected high salinity water is not well known. Bray (1988b) proposed that they travel south as mid-water gyres, which would then be mixed with the surrounding waters when passing over the sills. Palacios Hernández (2001) and López and García (2003) find 


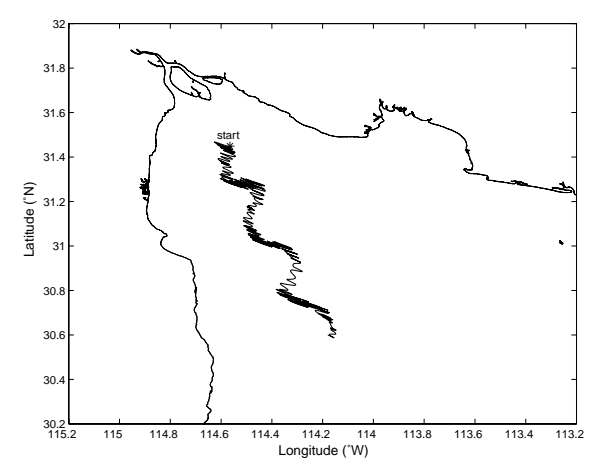

Figure 16. Progressive Vector Diagram from current meter data collected from June 29 to August 22, 1999. Initial position marked by *. Current meter was located $5 \mathrm{~m}$ above the bottom in mean bottom depth $15 \mathrm{~m}$. Although the map of the coast and the PVD are in the same scale, the diagram is an artifice and represents no physical trajectory.

evidence that winter water-mass formation events may be able to alter the circulation and thermohaline structure in the entire NGC.

\subsection{THE UPPER GULF OF CALIFORNIA}

The UGC is the shallow area (depth $<30 \mathrm{~m}$ ) at the northern end of the GC (Figure 1). It is a tidal, evaporative basin (1 m/year) subjected to strong tidal mixing (Argote et al., 1995; García Silva and Marinone, 2000), which keeps it vertically mixed. During spring (neap) tides, the tidal range is $6.4 \mathrm{~m}(1.7 \mathrm{~m})$ (Figure 3) and the tidal currents are about $0.5 \mathrm{~ms}^{-1}(0.1$ $\mathrm{ms}^{-1}$ ). Before the Colorado River was dammed, the UGC was an estuarine environment, at least during the peak river discharge (Carbajal et al., 1997; Lavín and Sánchez, 1999). Today the UGC is an inverse estuary throughout the year (Lavín et al., 1998).

Lavín et al. (1998) suggested that gravity currents might be important in the UGC, and be modulated by the spring-neaps cycle, with events occurring during neap tides; recent surveys and moored current meter observations confirm this. A most compelling evidence for the existence, and fortnightly modulation, of gravity currents in the UGC is the progressive vector diagram (PVD) from a current meter deployed in the center of the UGC during the summer of 1999 (Figure 16). During spring tides there is a weak eastward residual flow, but during neap tides there is a strong southward flow.

It has been proposed from the distribution pattern of temperature, salinity and bottom sediments, that the residual circulation pattern of the UGC consists of inflow in the mainland side and outflow in the peninsula side 
(Alvarez-Borrego et al., 1975; Carriquiri and Sánchez, 1999). Current meter data obtained in the summer of 1999 suggest that the residual circulation pattern may indeed be as described, driven by the fortnightly gravitycurrent events on the western side of the UGC. The gravity currents have speeds 0.02 to $0.07 \mathrm{~ms}^{-1}$, and are concentrated in a relatively small portion of the western side of the entrance to the UGC. The heat and salt budgets suggest that the gravity currents play an important role in the flushing of the UGC. Although the largest resuspension of sediments in the UGC occur during spring tides, significant near-bottom suspended sediment fluxes out of the UGC occur only during neap tides, driven by the gravity currents (Alvarez and Jones, 2002).

\section{Interannual variability}

The strongest interannual anomalies in the GC are due to the ENSO phenomenon (Baumgartner and Christensen, 1985; Bray and Robles, 1991), which is not surprising considering that its entrance is located in the coastal wave guide at only $23^{\circ} \mathrm{N}$. The phase speed of CTWs that carry the oceanic El Niño signal along the ETPac coast is $100-240 \mathrm{~km}$ per day (Strub and James, 2002b,c and references therein), so that it can reach the GC entrance in about one month. The anomalies observed just outside and inside the GC during an El Niño (Baumgartner and Christensen, 1985; Robles and Marinone, 1987; Ripa and Marinone, 1989; Marinone, 1989; Torres Orozco, 1993; Soto et al., 1999; Filonov and Tereshchenko, 2000; Castro et al., 2000; Durazo and Baumgartner, 2002; Strub and James, 2002b,c; Lavín et al., 2003) are explained by the properties of the internal CTWs: a 10$30 \mathrm{~cm}$ surface elevation, a 50-100 $\mathrm{m}$ deepening of the surface mixed layer and the thermocline (and a consequent increase in the heat content of the upper 100-200 m). The surface temperature elevation (up to $3{ }^{\circ} \mathrm{C}$ ) and surface salinity depression (0.1) are associated to the advective properties of a surface-elevation CTW in the presence of horizontal SST and salinity gradients. As noted above, the currents under surface-elevation CTWs are in the direction of travel of the wave (Martínez and Allen, 2003a,b), so that it looks like a burst or enhancement of the Costa Rica Coastal Current, as proposed by Baumgartner and Christensen (1985). The surface distribution of salinity inside the GC in March and August 1983 (see figures in Lavín et al., 1997b and 2003), in the decay phase of the 1982-83 El Niño, show TSW $(S<35)$ almost to the archipelago, while those in January and March 1984 represent the return to normal conditions with TSW retreating from the GC.

The interannual anomalies in the 17-year AVHRR SST record (Soto et al., 1999; Lavín et al., 2003) clearly show that during El Niño (La Niña) 
the monthly-mean temperature in the GC can be up to $3{ }^{\circ} \mathrm{C}$ above (below) normal. The positive anomalies are largest around the archipelago thermal fronts. There are other anomalies that are as large as those produced by a mid-strength El Niño but not associated to ENSO (e.g. summer of 1990 and in the winter of 1994-1995), which can produce noticeable effects in the hydrography of the GC (Palacios-Hernández, 2001).

The trend in the AVHRR SST is large and statistically significant (Lavín et al., 2003), amounting to a surface heating of $1{ }^{\circ} \mathrm{C}$ over the 17 years of the AVHRR record. This trend in the GC SST, which has also been observed in the COADS data set (Lluch-Cota, 2000; Bernal et al., 2001), appears to be part of the interdecadal variability, which has been producing a mean SST increase of the entire PO since the mid 1970s.

\section{Conclusion}

We understand much more about the physical oceanography of the Gulf of California than twenty years ago. However, as knowledge advances and as models and remote sensing become more powerful and usable, it is becoming apparent that more and sustained direct observations are needed in order to test current and future hypothesis and models, and to be able to use this knowledge for practical applications. From the early investigations in the GC it has been recognized that its extreme biological richness is due to physical factors (Gilbert and Allen, 1943; Alvarez-Borrego and Lara-Lara, 1991), but only recently have we began to unravel why and how it occurs. Tidal mixing must be highlighted in this respect.

The seasonal cycle has been submitted to close scrutiny (following the lead of Pedro Ripa), and research in the subject continues, especially in the water exchange across the mouth and between the NGC and the SGC. The study of mesoscale phenomena and processes with shorter time scales (e.g., geostrophic gyres, upwelling, plumes and fronts, gravity currents, etc.), and their influence upon the mean and seasonal circulation and thermodynamics is a standing challenge for observationalists and modelers.

\section{Acknowledgements}

This article is a tribute to the intellectual and humanistic inheritance left by Pedro Ripa (1946-2001). This work was supported by CICESE through regular budget, and by CONACYT (México) through contracts 25555T9712 and 35251T. We thank the colleagues who made available their published or unpublished writings and data, and those that reviewed drafts of this article: A. Martínez, A. Mascarenhas, R. Castro, F.J. Beron-Vera, 
P.T. Strub and others. We thank the technical support of C. Cabrera, V. Godínez and A. Ocampo.

\section{References}

Alvarez-Borrego S., B.P. Flores-Baez and L.A. Galindo-Bect. Hidrologia del Alto Golfo de California II. Condiciones durante invierno, primavera y verano. Cienc. Mar., 2, 21-36, 1975.

Alvarez-Borrego, S. and R. S. Schwartzlose. Masas de agua del Golfo de California. Cienc. Mar., 6, 43-63, 1979.

Alvarez-Borrego, S., and J.R. Lara-Lara. The physical environment and primary productivity of the Gulf of California. In The Gulf and Peninsular Province of the Californias, Mem. Am. Assoc. Pet. Geol., 47, 555-567, 1991.

Alvarez, L.G. and S.E. Jones. Factors influencing suspended sediment flux in the Upper Gulf of California. Est. Coast. Shelf Sci., 54, 747-759, doi: 10.1006/ecss.2001.0873, 2002.

Argote M. L., A. Amador, M. F. Lavín and J. R. Hunter. Tidal dissipation and stratification in the Gulf of California. J. Geophys. Res. 100, 16103-16118, 1995.

Argote, M.L., M.F. Lavín and A. Amador. Barotropic residual circulation due to M2 and wind stress in the Gulf of California. Atmósfera, 11, 173-197, 1998.

Badan-Dangon A., C. J. Koblinsky and T. Baumgartner. Spring and sumer in the Gulf of California: observations of surface thermal patterns. Oceanol. Act., 8, 13-22 pp, 1985.

Badan-Dangon A., M. C. Hendershott and M. F. Lavín. Underway Doppler current profiles in the Gulf of California, Eos, Trans. Am. Geophys. U., 72, 209, 217-218, 1991a.

Badan-Dangon A., C.E. Dorman, M.A. Merrifield and C.D. Winant. The lower atmosphere over the Gulf of California, J. Geophys. Res., 96, 16,877-16,896, $1991 \mathrm{~b}$.

Badan-Dangon, A. Coastal circulation from the Galápagos to the Gulf of California. In Robinson, A. and K.H. Brink (Eds.) The Sea, 11, 315-343, 1998.

Badan, A. The atmosphere over the Gulf of California. This volume.

Baumgartner T. R. and N. Christensen. Coupling of the Gulf of California to large-scale interannual climatic variability. J. Mar. Res. , 43, 825-848, 1985.

Beier, E. A numerical investigation of the annual variability in the Gulf of California, $J$. Phys. Oceanogr., 27, 615-632, 1997.

Beier, E. and P. Ripa. Seasonal gyres in the northern Gulf of California. J. Phys. Oceanogr., 29, 302-311, 1999.

Beier E. Estudio de la marea y la circulación estacional en el Golfo de California mediante un modelo de dos capas heterogéneas. Ph. D. thesis, Department of Physical Oceanography, CICESE, Ensenada, B.C., México, 64 pp, 1999.

Bernal, G., P. Ripa and J.C. Herguera. Oceanographic and climatic variability in the lower Gulf of California: links with the tropics and North Pacific. Cienc. Mar., 27, 591-617, 2001.

Beron-Vera, F. J. and P. Ripa. Three-dimensional aspects of the seasonal heat balance in the Gulf of California. J. Geophys. Res., 105, 11441-11457, 2000.

Beron-Vera, F.J. and P. Ripa. Seasonal salinity balance in the Gulf of California. J. Geophys. Res. 107, 10.1029/2000JC000769, 2002.

Bray, N. A. 1988a. Thermohaline circulation in the Gulf of California, J. Geophys. Res., 93, 4993-5020. 
Bray, N. A. Water mass formation in the Gulf of California, J. Geophys. Res., 93, 92239240, 1988b.

Bray, N. A. and J.M. Robles. Physical Oceanography of the Gulf of California. In The Gulf and Peninsular Province of the Californias, Mem. Am. Assoc. Pet. Geol., 47, 511-553, 1991.

Carbajal, N. Modelling of the circulation in the Gulf of California. Ph.D. Thesis, Institut für Meerskunde, Universität Hamburg, Germany, 186 pp, 1993.

Carbajal, N., A. Souza and R. Durazo. A numerical study of the ex-ROFI of the Colorado River. J. Mar. Sys., 12, 17-33, 1997.

Carbajal, N. and J.O. Backhaus. Simulation of tides, residual flow and energy budget in the Gulf of California. Oceanol. Act., 21, 429-446, 1998.

Carriquiry, J.D. and A. Sánchez. Sedimentation in the Colorado River Delta and Upper Gulf of California after a century of discharge loss. Marine Geology, 158, 125-145, 1999.

Carrillo L., M.F. Lavín and E. Palacios-Hernández. Seasonal evolution of the geostrophic circulation in the northern Gulf of California. Est. Coast. Shelf Sci., 54, 157-173, 2002.

Castro R., M. F. Lavín and P. Ripa. Seasonal heat balance in the Gulf of California, J. Geophys. Res., 99, 3249-3261, 1994.

Castro R., A. S. Mascarenhas, R. Durazo, C. A. Collins. Seasonal variation of the temperature and salinity at the entrance to the Gul of California, México. Cienc. Mar., 26, 561-583, 2000.

Castro Valdez, R. Variabilidad termohalina e intercambios de calor, sal y agua en la entrada al Golfo de California. PhD thesis, Facultad de Ciencias Marinas, UABC, Ensenada, México. 121pp, 2001.

Christensen, N., R. de la Paz and G. Gutiérrez. A study of sub-inertial waves off the west coast of Mexico. Deep Sea Res., 30, 835-850, 1983.

Collins, C.A., N. Garfield, A.S. Mascarenhas Jr., M.G. Spearman and T.A. Rago. Ocean currents across the entrance to the Gulf of California. J. Geophys. Res., 102, 20,92720,936, 1997.

Durazo, R. and T. Baumgartner. Evolution of oceanographic conditions off Baja California: 1997-1999. Progr. Oceanogr. 54, 7-31, 2002.

Emilsson, I., and M.A. Alatorre. Evidencias de un remolino ciclónico de mesoescala en la parte sur del Golfo de California. In M.F. Lavín (Editor) Contribuciones a la Oceanografía Física en México. Monografía No. 3, Unión Geofísica Mexicana, 173-182, 1997.

Enfield, D.B. and J.S. Allen. The generation and propagation of sea level variability along the Pacific coast of Mexico. J. Phys. Oceanogr., 13, 1012-1033, 1983.

Fiedler, P.C. Seasonal Climatologies and variability of Eastern tropical Pacific surface waters. NOAA Technical Report NMFS 109. U.S Department of Commerce, 65pp, 1992.

Figueroa, M., G. Marinone and M.F. Lavín. Geostrophic gyres in the southern Gulf of California. This volume.

Filloux, J.H. Tidal patterns and energy balance in the Gulf of California. Nature, 243, 217-221, 1973.

Filonov, A. and I. Tereshchenko. El Niño 1997-98 monitoring in mixed layer at the Pacific Ocean near Mexico's west coast. Geophys. Res. Lett., 27. 705-707, 2000.

Filonov, A.E. and M.F. Lavín. Internal tides in the northern Gulf of California. J. Geophys. Res, in the press, 2003.

$\mathrm{Fu}$, L.L. and B. Holt. Internal waves in the Gulf of California: Observations from a spaceborne radar, J. Geophys. Res., 89, 2053-2060, 1984. 
García-Silva and S.G. Marinone. Tidal dynamics and energy budget in the Gulf of California. Cienc. Mar., 27, 323-353, 2000.

Gaxiola-Castro, G., S. Álvarez-Borrego, S. Nájera-Martínez and A.R. Zirino. Internal waves effect on the Gulf of California phytoplankton. Cienc. Mar., 28, 297-309, 2002.

Gilbert, J.Y. and W.E Allen, The phytoplankton of the Gulf of California obtained by the E.W. Scripps in 1939 and 1940, J. Mar. Res., 5: 89-110, 1943.

Godínez, V.M., M.F. Lavín, J.M. Robles, R. Ramírez and C. E. Cabrera. Datos hidrográficos de la primera campaña del B/O Francisco de Ulloa al Golfo de California (diciembre de 1993). 2001. Comun. Acad., CICESE, Ensenada, B.C., México. CTOFT20011, 206 pp., 2001.

Griffiths, R.C. Physical, Chemical, and Biological Oceanography of the entrance to the Gulf of California, spring of 1960. Spec. Sci. Rep. U.S. Fish Wild Serv. No. 573, 43 pp, 1968.

Jiménez Lagunes, A. Análisis de las corrientes de marea y series de temperatura en la parte norte del Golfo de California. Tesis de Maestría, CICESE, Ensenada, B.C., México. 84 pp, 2003.

Lavín M. F. and S. Organista. Surface heat flux in the northern Gulf of California. $J$. Geophys. Res., 93, 14033-14038, 1988.

Lavín M. F., G. Gaxiola-Castro and J. M. Robles. Winter water masses and nutrients in the northern Gulf of California. J. Geophys. Res., 100, 8587-8605, 1995.

Lavín, M.F., R. Durazo, E. Palacios, M.L. Argote, and L. Carrillo. Lagrangian observations of the circulation in the northern Gulf of California. J. Phys. Oceanogr., 27, 2298-2305, 1997a.

Lavín M. F., E. Beier and A. Badan. Estructura Hidrográfica y Circulación del Golfo de California: Escalas estacional e interanual, Contribuciones a la Oceanografía Física en México, Unión Geofísica Mexicana, Monografía No. 3: 141-171, 1997b.

Lavín, M.F., V. Godínez and L.G. Alvarez. Inverse-estuarine features of the Upper Gulf of California. Est. Coast. Shelf Sci., 46, 769-795, 1998.

Lavín, M.F., and S. Sánchez. On how the Colorado River affected the hydrography of the Upper Gulf of California. Cont. Shelf Res., 19, 1545-1560, 1999.

Lavín, M.F., E. Palacios-Hernández and C. Cabrera. Sea surface temperature anomalies in the Gulf of California. Geofis. Int., in the press, 2003.

Lluch-Cota, S.E. Coastal upwelling in the Eastern Gulf of California. Oceanol. Act., 23, 731-740, 2000

López, M. A numerical simulation of water mass formation in the northern Gulf of California during winter. Cont. Shelf Res., 17, 1581-1607, 1997.

López, M. and J. García. Moored Observations in the Northern Gulf of California: a strong bottom current. J. Geophys. Res. 108, 3048, doi:10.1029/2002JC001492, 2003.

Marinone, S. G. Una nota sobre la variabilidad no estacional de la región central del Golfo de California. Cienc. Mar., 14, 117-134, 1988.

Marinone, S.G. and P. Ripa. Geostrophic flow in the Guaymas Basin, central Gulf of California. Cont. Shelf Res., 8, 159-166, 1988.

Marinone, S.G. Tidal residual currents in the Gulf of California: is the M2 tidal constituent sufficient to induce them?. J. Geophys. Res. 102, 8611-8626, 1997.

Marinone, S.G. Tidal Currents in the Gulf of California: Intercomparison among twoand three-dimensional models with observations. Cienc. Mar., 26, 275-301, 2000.

Marinone, S.G. A three dimensional model of the mean and seasonal circulation of the Gulf of California. J. Geophys. Res., submitted, 2003.

Marinone, S.G. and M.F. Lavín. Residual circulation and mixing in the large islands region of the central Gulf of California. This volume. 
Martínez Alcalá, J.A. Modeling studies of mesoscale circulation in the Gulf of California. PhD thesis, Oregon State University, 173 pp, 2002.

Martínez, J.A. and J.S. Allen. A modeling study of coastal-trapped wave propagation in the Gulf of California. Part 1: response to remote forcing. J. Phys. Oceanogr., in the press, 2003a.

Martínez, J.A. and J.S. Allen. A modeling study of coastal-trapped wave propagation in the Gulf of California. Part 2: response to idealized forcing. J. Phys. Oceanogr., in the press, 2003b.

Mascarenhas Jr., A.S., R. Castro, C.A. Collins and R. Durazo. Seasonal variation of geostrophic velocity and heat flux at the entrance to Gulf of California, Mexico. Unpublished manuscript, 2003.

Merrifield, M.A. and C.D. Winant. Shelf circulation in the Gulf of California: a description of the variability. J. Geophys. Res., 94, 18,133-18,160, 1989.

Morales, R.A. and G. Gutiérrez. Mareas en el Golfo de California. Geophís. Int., 28, 25-46, 1989.

Navarro-Olache, L.F., M.F. Lavín, L.G. Alvarez-Sánchez and A.R. Zirino. Internal structure of SST features in the central Gulf of California. Deep Sea Res., submitted, 2003.

Paden, C.A., M.R. Abbott, and C.D. Winant. Tidal and atmospheric forcing of the upper ocean in the Gulf of California, 1, Sea surface temperature variability. J. Geophys. Res., 96, 18,337-18, 359, 1991.

Paden, C.A., C.D. Winant, and M.R. Abbott. Tidal and atmospheric forcing of the upper ocean in the Gulf of California, 2, Surface heat flux, J. Geophys. Res., 98, 20,091-20, 103, 1993.

Palacios Hernández, E. Circulación de la región norte del Golfo de California: estacional y anomalías. PhD thesis, CICESE, Ensenada, México, 117pp, 2001.

Palacios-Hernández, E., E. Beier, M.F. Lavín, and P. Ripa. The effect of winter mixing on the circulation of the Northern Gulf of California. J. Phys. Oceanogr., 32, 705-728, 2002.

Parés-Sierra, A., A. Mascarenhas, S.G. Marinone and R. Castro. Temporal and spatial variation of the surface winds in the Gulf of California. Geophys. Res. Lett., 30(6), 1312, doi:10.1029/2002GL016716, 2003.

Pegau W.S., E. Boss and A. Martinez. Ocean color observations of eddies during the summer in the Gulf of California. Geophys. Res. Lett. 29, doi:10.1029/2001GL014076, 2002.

Ramírez-Manguilar, A.M. Análisis armónico de datos de corrientes en la región norte del Golfo de California de noviembre de 1994 a febrero de 1996. BSc thesis, Facultad de Ciencias Marinas, UABC, Ensenada, B.C., México, 56 pp, 2000.

Reyes A. C. and M. F. Lavín. Effects of the autumn-winter meteorology upon the surface heat loss in the Northern Gulf of California. Atmósfera, 10, 101-123, 1997.

Ripa, P., and S.G. Marinone. Seasonal variability of temperature, salinity, velocity, vorticity and sea level in the central Gulf of California, as inferred from historical data. Quart. J. Roy. Met. Soc., 115, 887-913, 1989.

Ripa, P. Seasonal circulation in the Gulf of California, Ann. Geophys., 8, 559-564, 1990.

Ripa, P. and G. Velázquez. Modelo unidimensional de la marea en el Golfo de California. Geofís. Intl., 32, 41-56, 1993.

Ripa, P. Towards a physical explanation of the seasonal dynamics and thermodynamics of the Gulf of California, J. Phys. Ocean, 27, 597-614, 1997.

Robles J. M. and S. G. Marinone. Seasonal and interannual thermoaline variability in the Guaymas Basin of the Gulf of California. Cont. Shelf Res., 7, 715-733, 1987. 
Roden, G.I. Oceanographic and meteorological aspects of the Gulf of California. Pacific Science, XII, 21-45, 1958.

Roden, G.I., and G.W. Groves. Recent oceanographic investigations in the Gulf of California, J. Mar. Res., 18, 10-35, 1959.

Roden, G. I. Oceanographic aspects of Gulf of California. In: T. H. Van Andel and G. G. Shor Jr. (Eds.) Marine Geology of the Gulf Of California: A symposium. Am. Assoc. Pet. Geol. Mem., 3, 30-54 pp, 1964.

Roden, G.I. Aspects of the transition zone in the Northeastern Pacific. J. Geophys. Res., 76, 3462-3475, 1971.

Roden, G.I. Termohaline structure and baroclinic flow across the Gulf of California entrance and in the Revilla Gigedo Islands region. J. Phys. Oceanogr., 2, 1777-1803, 1972.

Romero Centeno R. D. L. Comportamiento de los campos hidrográficos y flujos de calor y masa en el Canal de Ballenas. M. Sc. thesis, Department of Physical Oceanography, CICESE, Ensenada, B.C., México, 126 pp, 1995.

Santamaría-del-Angel, E., S. Alvarez-Borrego and F.E. Müller-Karger. Gulf of California biogeographic regions based on coastal zone color scanner imagery. J. Geophys. Res., 99, 7411-7421, 1994.

Simpson, J.H., A.J. Souza, and M.F. Lavín. Tidal mixing in the Gulf of California, in Mixing and Transport in the Environment, edited by K.J. Beven, P.C. Chatwin, and J.H. Millbank, pp. 169-182, John Wiley, New York, 1994.

Soto-Mardones L. A., S. G. Marinone and A. Parés-Sierra. Time and spatial variability of sea surface temperature in the Gulf of California, Cienc. Mar., 25, 1-30, 1999.

Stevenson, M.R. On the physical and biological oceanography near the entrance of the Gulf of California, October 1966-August 1967. Bull. Inter-Am. Trop. Tuna Comm., 14, 389-504, 1970.

Strub, P. T. and C. James. Altimeter-derived surface circulation in the large-scale NE Pacific Gyres. Part 1. seasonal variability. Progr. Oceanogr., 53, 163-183, 2002a.

Strub, P. T. and C. James. Altimeter-derived surface circulation in the large-scale NE Pacific Gyres. Part 2: 1997-1998 El Niño anomalies. Progr. Oceanogr., 53, 185-214, 2002b.

Strub, P. T. and C. James. The 1997-1998 oceanic El Niño signal along the southeast and northeast Pacific boundaries-an altimetric view. Progr. Oceanogr., 54, 439-458, 2002c.

Torres Orozco, E. Análisis Volumétrico de las masas de agua del Golfo de California. M. Sc. Thesis. CICESE, Ensenada, B.C, México, 80 pp, 1993.

Wyrtki, K. Surface Currents in the Eastern Tropical Pacific. Bull. Inter-Am. Trop. Tuna Comm., , Vol. IX, No. 5., 269-303, 1965.

Wyrtki, K. Oceanography of the Eastern Ecuatorial Pacific Ocean. Oceanogr. Mar. Biol. Ann. Rev., 4, 33-68, 1966.

Wyrtki, K. Circulation and water masses in the Eastern Ecuatorial Pacific Ocean. Intl. J. Oceanol. \& Limnol., 1, 117-147, 1967.

Zamudio, L., H.E. Hurlburt, E.J. Metzger and O.M. Smedstad. On the evolution of coastally trapped waves generated by Hurricane Juliette along the Mexican west coast. Geophys. Res. Lett., 29. doi: 10.1029/2002GL014769, 2002. 